\title{
Gender differences in the schooling experiences of adolescents in low-income countries: The case of Kenya
}

\author{
Barbara Mensch \\ Population Council \\ Cynthia B. Lloyd \\ Population Council
}

Follow this and additional works at: https://knowledgecommons.popcouncil.org/departments_sbsr-pgy

Part of the Demography, Population, and Ecology Commons, Educational Sociology Commons, Family, Life Course, and Society Commons, Gender and Sexuality Commons, and the International Public Health Commons

How does access to this work benefit you? Let us know!

\section{Recommended Citation}

Mensch, Barbara and Cynthia B. Lloyd. 1997. "Gender differences in the schooling experiences of adolescents in low-income countries: The case of Kenya," Policy Research Division Working Paper no. 95. New York: Population Council. Version of record: https://doi.org/10.2307/172157 


\title{
Gender Differences in the Schooling Experiences of Adolescents in Low-Income Countries: The Case of Kenya
}

\author{
1997 No. 95
}

Barbara S. Mensch

Cynthia B. Lloyd 


\title{
Gender Differences in the Schooling Experiences of Adolescents in Low-Income Countries: The Case of Kenya
}

\author{
Barbara S. Mensch \\ Cynthia B. Lloyd
}

Barbara S. Mensch is Associate, Policy Research Division, Population Council. Cynthia B. Lloyd is Senior Associate and Director of Social Science Research, Policy Research Division, Population Council.

Paper prepared for the National Academy of Sciences Committee on Population's "Workshop on Adolescent Sexuality and Reproductive Health in Developing Countries: Trends and Interventions," Washington, DC, 24-25 March 1997. Also presented at the 1997 Annual Meeting of the Population Association of America, Washington, DC, 27-29 March. 


\begin{abstract}
Little research on education in developing countries has focused on adolescent issues; at the same time, despite the fact that a growing proportion of young people are spending some time in school between puberty and marriage, there is little research on schooling as a key dimension of the adolescent experience. This paper examines the school environment in Kenya and the ways it can help or hinder adolescents. We focus on gender differences with a view toward illuminating some of the factors that may present particular obstacles or opportunities for girls.

The paper reviews what is known about schooling and adolescence, focusing on what the literature can tell us about the relationship between adolescent schooling and "successful" transitions to adulthood, including not only the development of cognitive competencies, but also the fulfillment of personal educational goals, the avoidance of pregnancy, and the development of self-esteem and empowerment of young women. While the demographic literature views education as uniformly positive, leading women to delay marriage and childbearing, the education literature views schools as conservative institutions that reinforce gender inequality in the society.

Using both qualitative and quantitative data, the paper then analyzes 36 primary schools in rural areas in three districts of Kenya, chosen to reflect the spectrum of school quality in the country. The focus is on primary schools because the majority of adolescents in school attend primary school. In schools that encompass the range in terms of performance and parental status, disorganization coexists with strict punishment, minimal comforts are lacking, learning materials are scarce, learning is by rote, and sex is practiced but not taught. Girls do worse than boys in the primary school leaving exam, and high-performing schools are not necessarily more gender equitable. Teachers' attitudes and behavior reveal lower expectations for adolescent girls, traditional assumptions about gender roles, and a double standard about sex.
\end{abstract}

This material may not be reproduced in any form without written permission from the authors. 


\section{Acknowledgments}

We worked with many collaborators in our field study in Kenya, and each one brought special talents to the collaboration. We first acknowledge the official support of Kenya's Ministry of Education and the Office of the President, in particular the collaboration of Elizabeth Masiga, the Chief Inspector of Schools, and her deputies in the area of family life education: Prisca Makhulo and Paul Matogo. Our research team included Ayorinde Ajayi as Project Director, Annabel Erulkar as adolescent specialist, Karin Hyde as educational consultant, and Cecilia Ndeti as field study coordinator. We are also grateful to the six field supervisors and 12 research assistants who collected the data from adolescents and schools in the three districts. Others who provided special assistance were Ian Diamond on the sampling design and John Kekovole on the selection of clusters from the national sampling frame.

We also thank members of two advisory groups convened to support the work of this project. The first was organized by the Forum for African Women Educationalists based in Nairobi and chaired by Eddah Gachukia. Members include Okwach Abagi, Florence Kiragu, Salome Kirea, Benjamin Makau, Karega Mutahi, and Margaret Wanjohi. The second advisory group was organized by the Population Council in New York to guide the Council's work on Schooling and the Experience of Adolescents. This group included Thomas Eisemon, Bruce Fuller, Elizabeth King, Marlaine Lockheed, Joyce Moock, Andrea Rugh, and Patience Stephens.

At the early stage of project development, we had very useful conversations with Patricia Campbell of Campbell-Kibler Associates; Paul Glewwe, Elizabeth King, and Paud Murphy at the World Bank; David Sadker at American University; and Jane Schubert at the Institute for International Research.

Invaluable assistance was provided by Wesley Clark in the cleaning and processing of data and by Barry Ravitch in the layout of the survey instruments and training manuals and the design of the data entry screens. Financial support has been provided by Ford Foundation-Nairobi, Ford Foundation-New York, Pew Charitable Trusts, USAID, Wallace Global Fund, UNFPA-Nairobi, and the Population Council. Helpful comments were provided by Sajeda Amin. 
A growing proportion of young people in Africa are spending some time in school between puberty and marriage. At the same time, this phase of the life cycle between physical and social maturity-typically defined as adolescence - is lengthening, due in part to higher adolescent enrollments in school. As a result, the school is an increasingly important institution in the socialization and training of the next generation. In premodern society, training and preparation for adulthood was exclusively a family and community affair. The onset of puberty was often the occasion for sexually segregated rituals to signal the beginning of adulthood, at which time information about sexuality, reproduction, and adult roles was shared between men and boys and between women and girls. Now children are likely to be in school at the time of physical maturation and, therefore, exposed to nonfamilial attitudes, information, and ideas from teachers, peers, and a centrally designed curriculum.

Thus, understanding what happens to adolescents within the school environment becomes critical to understanding the contemporary experience of adolescence in Africa. Where transportation and communication are poor and where many parents are themselves illiterate, school provides a setting in which children can meet authority figures other than their parents, acquire specific academic and life skills, and learn about the world that lies beyond their local community. For girls, in particular, even more may be at stake; school may be the only place where they can meet women in the work place and learn that existing gender roles and competencies are potentially challengeable and changeable. The effects of schooling on the children who experience it may be enormous, encompassing not only the development of cognitive competencies that will affect their adult productivity, but also the formation of values, norms, and aspirations that will affect other dimensions 
of their lives, in particular the types of families formed and the roles played within them.

Little research on education in developing countries has focused on adolescent issues; at the same time, little research on adolescents in Africa has gone beyond an interest in family life education in school to a broader exploration of schooling as a key dimension of adolescent experience.

Recognizing the critical importance of schools as a socializing agent, this study is designed to shed light on both research gaps by taking an in-depth look at the school environment and at the potential ways it can help or hinder adolescents. The data we present cover a range of contemporary schooling experiences of adolescents in three districts of Kenya, drawing on primary school data collected as part of a larger study of adolescents in Kenya. We focus in particular on two dimensions of the quality of the school environment for adolescents: those elements of the educational process that have some independent support in the educational literature as reflecting good practice either (1) from the point of view of developing cognitive competencies or (2) from the point of view of enhancing gender equity. Because adolescence is the phase of the life cycle when the roles and responsibilities of adulthood emerge and when gender differences become sharply defined, we feel that these two dimensions of the school environment will be important to assess if we are to understand the ways in which schools shape adult gender roles and influence later productive and reproductive outcomes.

Our special focus in this paper is gender differences. There has been little research in developing countries on what aspects of schooling are most important to girls' future productivity or to their reproductive health and the achievement of their reproductive goals. Furthermore, little is known about the determinants of educational continuity and success either at the school or 
at the family level. Our goal in describing the range of school experiences for adolescents in Kenya is to illuminate some of the factors that may present particular obstacles or opportunities for girls.

We begin with a review of what we know about schooling and adolescence from the literature. This is followed by some background on schooling in Kenya as well as on our school data. In presenting preliminary results from our field study, we categorize schools as "high-performing" or "low-performing" according to the relative performance of female students on the national exams, noting differences and similarities between the two groups in various dimensions of school quality. We base our conclusions on both qualitative and quantitative data from our school visits.

\section{A REVIEW OF THE Literature}

In preparing for this study, we consulted several bodies of literature: (1) demographic studies of adolescents (see Mensch, Greene, and Bruce 1997 for a recent review), (2) school effectiveness studies (see Fuller and Clarke 1994; Harbison and Hanushek 1992; Lockheed and Verspoor et al. 1991 for recent reviews), and (3) studies of the role of schools as socializing agents (see Stromquist 1989). The first body of literature on adolescents in developing countries addresses issues related to the timing of critical demographic events in the transition to adulthood such as first sex, marriage, and childbearing, as well as the use of fertility regulation and the incidence of sexually transmitted diseases. Schooling is recognized as a factor that can influence these events and is seen as an undifferentiated and unalloyed "good" by those who would like to see girls delay sex and childbearing. However, none of these studies has attempted to open the school house door to see what 
happens inside and how that might affect the outcomes of interest. The second body of literature on education in low-income countries views education as a production process and seeks to identify critical inputs to schooling that contribute to the development of cognitive competencies. Few insights can be found here about the context of adolescents' daily lives in school or about the ways in which schooling might reinforce or change adolescent learning and socialization with consequences for demographic outcomes. The final set of studies, which are not so easily grouped, were consulted for their insight into a more cultural understanding of formal Western school as a social institution situated within the larger society and its role in the socialization of boys and girls.

Rather than summarize the vast literature, we discuss what it can tell us about the relationship between adolescent schooling experiences and "successful" transitions to adulthood, including not only the development of critical cognitive competencies but also the fulfillment of personal educational goals, the avoidance of pregnancy, and the development of self-esteem and empowerment of young women. ${ }^{1}$

\section{Schooling and the demography of adolescents}

It appears to be universally true that those with no education or less than primary schooling tend to have earlier ages of marriage and higher fertility than those with primary schooling completion, with the fertility of secondary school graduates falling even lower (United Nations 1995; Jejeebhoy 1995; Ainsworth, Beegle, and Nyamete 1996). At the same time, the fertility of women with equal levels of schooling varies enormously between societies, as does the relationship between number of years of schooling and fertility among those who have attended only primary school. Little progress has been 
made in identifying what aspects of education matter for fertility, although several recent studies hypothesize that education's role in enhancing women's autonomy may be important (Jejeebhoy 1995; Glewwe 1996).

Some of the effects of schooling on fertility can be directly linked to the fact that prolonged school enrollment during adolescence leads to delays in age at marriage or first childbirth. At the same time, one must recognize that further schooling is typically only possible for young women who can avoid pregnancy or childbirth while they are in school. Thus part of our task must be to identify those aspects of schooling that might contribute not only to academic success and retention but also to the avoidance of pregnancy and childbirth. $^{2}$

In Africa, there is concern about the growing percentage of teenage births that occur among the unmarried. Furthermore, the rapid expansion in education has led to an increasing focus in the literature on the link between premarital childbearing and schoolgirl dropout (Ferguson 1988; Meekers, Gage, and Zhan 1995). However, there is no evidence that pregnancy is the principal reason for girls' early withdrawal from school. The only study that has attempted to quantify dropouts directly attributable to pregnancy did not collect data on dropouts for other reasons; thus, comparisons with other causes of dropout were not possible (Ferguson 1988). With reported dropouts due to pregnancy affecting only about 1 percent of girls in school each year, pregnancy is unlikely to be a leading proximate cause of early school leaving.

Furthermore, this literature implicitly assumes that girls who are forced to withdraw due to pregnancy would have continued in school if they had not become pregnant. Yet, there are many other reasons a girl might withdraw from school during her adolescence. And for those girls who do become 
pregnant, an unsupportive school environment may increase the chances that they will give birth rather than seek an abortion and continue in school. In short, rather than pregnancy causing girls to drop out, the absence of social and economic opportunities for girls and women and the demands placed on them, coupled with the gender inequities of the education system, may result in unsatisfactory school experiences, poor academic performance, and acquiescence in or endorsement of early motherhood. Such issues led us to explore the literature on education for what it can tell us about the association between the quality of the schooling experience-as it relates both to cognitive competencies and gender equity-and school retention and achievement.

\section{School quality and academic achievement}

The extent of the benefits an adolescent can get from a "good" school is directly tied to the amount of time s/he spends there. In studying the links between school quality and adolescent educational achievement, it is necessary to understand what school characteristics encourage enrollment, attendance, and retention. Studies of the determinants of school enrollment and attainment, however, have given primary attention to the measurement and assessment of family factors because of their clear importance (for example, Hill and King 1993; Lloyd and Blanc 1996) and little attention, beyond the anecdotal, to school factors. ${ }^{3}$ The relationship between school characteristics and the length of time adolescents spend in school is rarely explored directly (for two exceptions see Glewwe and Jacoby 1994; Hanushek and Lavy 1994); the evidence is primarily indirect and suggestive rather than conclusive (Card and Krueger 1996). 
Instead, educationalists and economists, in their research on the effects of schooling in developing countries, have focused primarily on the direct relationship between school quality (variously defined) and academic achievement as measured by student performance on standardized tests (Fuller and Clarke 1994; Harbison and Hanushek 1992; Lockheed and Verspoor et al. 1991; Fuller 1987; Heyneman and Loxley 1983) and only secondarily on unraveling the links between school inputs, enrollment and retention, and ultimate achievement (Card and Krueger 1996). These production function studies conclude that school quality matters for immediately measurable school outcomes (Hanushek 1995), but there is little consensus about how to define school quality or about what dimensions of quality actually make a difference. Indeed, quality is often measured not in terms of specific inputs but in terms of correlates such as resources per student or class size.

Furthermore, little attention has been given in this literature to teacher attitudes or classroom dynamics as elements of school quality or to those aspects of the school and classroom environment that may result in different experiences for boys and girls. One notable exception is Appleton (1995), who studied gender differences in exam performance in Kenya and found both parents' and teachers' attitudes about the natural ability of boys and girls to be significantly correlated with differentials in performance. The concern in including attitudinal variables in a production function of school inputs and outputs is that they may be jointly determined, in that gender differences in actual performance may be a factor in shaping teachers' attitudes. In order to identify attitudes that were formed outside the immediate context of the study, Appleton (1995) was careful to phrase questions to teachers and parents that apply to men and women or boys and girls in general. However, it is not clear that this eliminates judgments based on teachers' experiences at the school. 
Adapting the framework developed by Lockheed and Verspoor et al. (1991) to assess school effectiveness, we concentrate on evidence related to three broad elements of the educational process that have some independent support in the literature as being good practice from the point of view of academic achievement: (1) time to learn, such as hours spent in class and time spent using the available facilities; (2) material inputs, such as books, desks, libraries, labs, playing fields, and (3) effective teaching, such as pedagogical practices and teacher competency. Our interest here is in identifying ways in which these elements can have different implications for boys and girls even within the same school.

There is broad consensus that the amount of time effectively dedicated to learning in the classroom is directly related to positive educational outcomes (Lockheed and Verspoor et al. 1991). Many things can detract from learning time and some can affect boys and girls differently. School-based factors reducing learning time include disruptions due to teacher absence, ceremonial events, time out of class for chores or punishments, and excessive class size. Anecdotal evidence from West Africa suggests that girls are sometimes asked to do more domestic chores than boys, with the consequence that their learning time is reduced relative to boys (Biraimah 1980; AndersonLevitt, Bloch, and Soumare, forthcoming). One factor that is sometimes seen to increase learning time, particularly for girls, is sex-segregated classes or single-sex schools. Studies in Nigeria and Thailand have shown higher math achievement for girls in single-sex relative to mixed schools but lower achievement for boys when schools with similar resources are compared (Jimenez and Lockheed 1989; Lee and Lockheed 1990). One factor identified was the greater amount of time spent on instruction in all-girl schools. In addition, other dimensions of school quality discussed below can potentially 
affect learning time indirectly to the extent that they affect daily attendance rates. One example is the inadequacy of toilet facilities, which could deter girls from attending on days when they are menstruating. Another is the differential participation rates of boys and girls in teacher-student classroom interaction, leading to less opportunity for girls to be engaged in active learning (Grisay 1984).

Various material inputs affect school quality: these include (1) the availability of instructional materials (in particular, textbooks, desks, library, science lab), (2) the condition of and access to basic facilities (classrooms, toilets, and playing fields), (3) the availability of certain amenities (water, electricity, transport), and (4) school-specific elements of the curriculum that go beyond the core (such as sports and family life education). Over the past decade, researchers have found that the availability of textbooks and other instructional materials has a consistently positive effect on student achievement in developing countries (Heyneman and Loxley 1983). A recent study evaluated the impact on average test scores of increasing the supply of textbooks in poor schools in Kenya. The study found that the program stimulated such an increase in enrollment in the experimental schools that the positive effects of additional textbooks on test scores were negated by the negative consequences of increased enrollments (Kremer et al. 1996). This study provides direct evidence of the importance of school quality to enrollment and underscores the importance of disentangling effects of schooling on cognitive competencies from effects of schooling on enrollment and retention.

There has been less attention to other inputs, which, while less directly tied to academic learning, may have important implications for gender differences in the quality of the school experience and may affect girls' 
retention in school. We have already mentioned the potential consequences of inadequate toilet facilities for opportunities to learn. Lack of privacy in toilets can also provide opportunities for sexual harassment, a further discouragement to girls (see Anderson-Levitt, Bloch, and Soumare, forthcoming, for recent evidence from Guinea). On the other hand, the provision of family life education may benefit girls who find themselves in a vulnerable position in sexual negotiation. Another example is the provision of sports for girls, which is increasingly recognized as a means for developing self-confidence and a sense of personal mastery.

The most consistent finding with respect to teacher credentials and effective teaching is the importance of teachers' knowledge of the subject matter and their verbal proficiencies (Cleghorn, Merritt, and Abagi 1989; Fuller and Clarke 1994). There is no consistent evidence that girls perform better with female teachers than with male teachers (Abraha et al. 1991; Fuller, Hua, and Snyder 1994; Appleton 1995), except possibly in single-sex schools, where female teachers deal exclusively with female students (Lee and Lockheed 1990).

This production function approach to the study of education has led to many frustrations. School inputs that appear statistically important in one context are unimportant in other contexts. In a recent review of the literature, Fuller and Clarke (1994) make a strong appeal for the recognition of culture and context in the linking of inputs to outputs. They also draw our attention to another group of education researchers whom they classify as "classroom culturalists":

These observers of schools focus on the normative socialization that occurs within classrooms: the value children come to place on individualistic versus cooperative work, legitimated forms of 
adult authority and power and acquired attitudes toward achievement and modern forms of status. (p.120)

In the discussion that follows, we look for guidance from this literature on other aspects of schooling experiences that may be of particular importance to the socialization of boys and girls.

\section{Schooling, gender, and socialization}

In a modernizing society, formal Western-style schooling provides a new context within which socialization takes place. Traditional gender systems and modes of learning are adapted and reinterpreted in a new context. Bledsoe (1992) uses Sierra Leone to illustrate the ways in which Western education has been transformed to reflect the traditional culture. In traditional Mende society, knowledge is power; the elders within the community, who have special knowledge, control its access and seek gain in exchange for sharing it. Knowledge does not have value in itself unless it is imparted in the appropriate way. Through an exchange, the recipient is properly "blessed" and the giver is recompensed. "Since blessings legitimate rights to certain domains of knowledge, how children learn is as important as what they actually learn" (p.192). Bloch (1993), in a village study in rural Madagascar, explains the uncritical acceptance of knowledge acquired in school in terms of its association with the wisdom of elders in the community. The knowledge of elders is seen to be absolute and morally true because it emanates from the ancestors and beyond, but at the same time it is seen as irrelevant for practical day-to-day activities. The "chalk and talk" (Fuller and Snyder 1991) approach to teaching in most classrooms where the teacher is vocal, dominant, and often punitive takes on new meaning when we understand the link between traditional authority structures and the transmission of knowledge in different 
cultural contexts.

This approach to the transmission of knowledge gives teachers special power and authority and potentially makes girls, particularly during their adolescence, especially vulnerable. Both teachers and students bring their knowledge and experience with gender systems in the traditional culture into the classroom, and through the educational process these systems get adapted and reinforced through teacher-student and peer interaction (Davies 1994; Finn, Reis, and Dulberg 1982). In many countries with a colonial history, it is also the case that missionaries and colonial administrators heretofore used the schooling systems they helped to develop for their own ends (Yates 1982).

School-based studies often report negative expectations and attitudes toward girls on the part of both male and female teachers. In Togo, for example, teachers described their female students in negative terms such as "disruptive behavior" or "lacks interest in school" whereas they described male students as "responsible," "hardworking," and "scholarly"4 (Biraimah 1980). In Malawi teachers consider girls to be less "serious" and capable (Davidson and Kanyuka 1992), less interested in their school work, and sometimes lazy (Hyde 1997). In Guinea, teachers described boys as able to learn lessons well, more likely to participate in class and provide "good" responses to teachers' questions, and "ambitious," whereas girls were typically described as well-behaved but timid and not as hardworking as boys (Anderson-Levitt, Bloch, and Soumare, forthcoming).

The reasons teachers give for boys' better academic performance often appear to be due to negative attributes of girls rather than positive attributes of boys (Davidson and Kanyuka 1992). Of particular interest to this study were the responses of Kenyan primary school teachers in Appleton's study (1995) to the question: "Girls tend to do less well in the primary leaving exam. Why 
do you think this is?" The largest group of responses related to the effects of adolescence on girls, who become disturbed by their bodily changes, lose interest in school, become more interested in boys and in their own appearance, and suffer from mood swings. Other responses related to sexuality, immorality, and pregnancy. Male and female teachers gave similar responses, although female teachers were slightly more likely to mention adolescence and male teachers were more likely to mention girls' interest in boys.

Many of these same studies confirm that girls do indeed participate less in class, primarily because they volunteer less (Biraimah 1980; AndersonLevitt, Bloch, and Soumare, forthcoming). There is no systematic evidence that teachers are actively biased against the classroom participation of girls, in that they appear to select fairly from among those who volunteer, but their passive response to the sexual differentiation that emerges results in uneven treatment nonetheless (Biraimah 1989). This "fair" but passive behavior of teachers may be particularly powerful in reinforcing gender attitudes and expectations among students in a context where the culture prescribes different forms of knowledge and different styles of learning for boys and girls (Fuller, Hua, and Snyder 1994). It may also explain why the introduction of teaching practices that are positively viewed in the West, such as more openended questioning and discussion and the use of programmed teaching and instructional materials, may sometimes appear to accentuate gender differences rather than alleviate them. For example, Fuller, Hua, and Snyder (1994) found that teachers' greater use of open-ended questioning lessened girls' advantage in English learning. The introduction of a programmed teaching approach in Liberia resulted in improved performance on average for both boys and girls but greater gender differentiation in favor of boys than 
more conventional approaches (Boothroyd and Chapman 1987).

The day-to-day interaction in the classroom is heavily reinforced by centrally designed teaching materials, which rigidly reinforce cultural stereotypes. "In developing countries, textbooks transmit heavily stereotyped images of men and women, with women adopting low profiles and having traits of passivity, dependence on men, low intelligence and [a lack of] leadership" (Stromquist 1994: 2409). An analysis of the gendered context of Kenyan textbooks found images of women appearing much less frequently than men; when women are depicted, they are typically in a position subordinate to men, are portrayed in fewer types of roles, and their physical appearance is given more importance than achievement (Obura 1991). In some countries, a "home science" curriculum is exclusively designed for girls for the explicit purpose of reinforcing gender stereotyping by preparing girls for their socially prescribed roles (Herrera 1992).

Tensions between the traditional culture and formal schooling are particularly visible when children stay in school past the point of physical maturation. Parents in traditional society exert control over their daughters' sexuality; initiation ceremonies for both boys and girls that are tied to puberty define the beginnings of social adulthood. The knowledge gained during these ceremonies readies young men and women for marriage and a sexual life (Hyde and Kadzamira 1994). In such settings, the persistence of girls in school causes social confusion; a schoolgirl is viewed as a child from a social point of view, whereas a girl who has been initiated (or circumcised) is considered a social adult. One reason many school systems in developing countries are reluctant to introduce family life education may be that they see it as conveying privileged adult information to pupils who must remain "children" if they are to stay in school. 
Bledsoe (1990) emphasizes the symbolic importance of the school uniform, which, like the clothes worn by girls during initiation ceremonies, conveys their status as initiates or trainees who should be recognized as belonging to a protected class. However, in many settings wearing a uniform is not sufficient to protect girls from the sexual advances of fellow students and teachers. A schoolgirl's sexuality can be taken advantage of by powerful teachers who are able to manipulate their special position of privilege to seek recompense for their support or "blessings." At the same time, in a period of rapidly rising school fees, a schoolgirl's sexuality can become an asset, if carefully managed, to help her finance her school fees. Bledsoe (1990) describes the complex symbolism of school fees in the marriage negotiations of the Mende of Sierra Leone and the simultaneous risks and opportunities conveyed to girls through their participation in school as sexually mature adolescents.

The interesting contrast between this body of literature and the demographic literature previously reviewed is that each appears to be saying very different things about the benefits of schooling for girls. In the demographic literature, education is seen as uniformly positive in that it leads women to delay marriage and childbearing and ultimately to bear fewer children and to invest more in each. In the socialization literature, schools are seen as conservative institutions that reinforce gender inequality. It would seem that schools are simultaneously reinforcing existing gender bias and inducing more "modern" forms of behavior that have the potential to help women acquire greater autonomy. To understand the processes that underlie these apparently contradictory outcomes, the production function approach needs to be broadened to allow for the assessment of a wider range of inputs and outputs. On the input side, not enough attention has been given to teacher 
attitudes and classroom dynamics. On the output side, not enough attention has been given to school attendance and retention on the one hand and reproductive outcomes on the other. In this paper we address the first research gap; in subsequent research we plan to address both.

\section{SCHOOLING IN KENYA}

Primary school in Kenya consists of eight levels, or Standards. Most primary schools are co-educational government schools; relatively few primary schools have boarding facilities. Students who succeed in the national primary school leaving exam, the Kenyan Certificate of Primary Education (KCPE), can continue to secondary school, which lasts another four years.

In Kenya (as well as most other countries of sub-Saharan Africa) the majority of school-going adolescents attend primary school. This is the case for several reasons: (1) many children start school after the normal starting age (Lloyd and Blanc 1996; Glewwe and Jacoby 1993); (2) grade repetition occurs because of irregular attendance due to familial demands on children's time, nonpayment of school fees, and the need for extra preparation time before sitting for national exams; and (3) national exams administered at the end of primary school are designed to ration access to the far fewer places in secondary schools (Appleton 1995). Surprisingly, despite this age pattern of attendance, the limited research on adolescents in schools is often based on samples of secondary school students (see, for example, Youri 1993).

At the beginning of adolescence, enrollment rates in Kenya are high (over 90 percent at age 12), but the large majority of adolescents are behind grade for their age, due to late ages of entry and grade repetition. Only 79 
percent of children aged 14 have completed Standard 4 out of the eight Standards (grades) in primary school (Lloyd and Blanc 1996). Enrollment rates fall off steadily during the teenage years, reaching roughly 57 percent by age 18 (Montgomery and Lloyd 1996). No more than 40 percent of those leaving primary school are able to go on to public secondary schools because of limited places.

In Kenya, overall enrollment rates for boys and girls are roughly on a par at the younger ages (Lloyd and Blanc 1996). Gender differentials emerge in grade progression, exam performance, and dropout rates during the teenage years. Among 10-14-year-olds who have ever attended school, 49 percent of girls and 57 percent of boys have completed Standard 4. For those under age 19 who have completed some primary school, the percentage of girls who have dropped out during the primary school years is estimated to be 31 percent higher than for boys (Appleton 1991). Furthermore, girls perform poorly relative to boys in the KCPE. In all required subjects except Kiswahili and English, girls do worse than boys (Makau 1994). The mean gender difference is greater than or equal to a third of a standard deviation in Math, Science, and Humanities (Appleton 1995).

There is enormous variation in facilities and other aspects of school quality among Kenyan government primary schools. Because fees are set by each school through the parent-teacher associations, they vary according to parental willingness and ability to pay. Government funding is limited to teachers' salaries, with parents paying building costs and other recurrent costs. Recent estimates suggest that parents pay nearly 60 percent of the cost of primary schooling in Kenya (Appleton 1995a). Parents are not obligated to send their children to a particular school. Within communities, there is some choice for parents, with children from small geographic areas distributing 
themselves among several primary schools.

Although the quality of the facilities differs across schools, some aspects of primary schooling do not vary or, at least, should not vary because they are mandated by the Ministry of Education. As indicated above, at the end of primary school students are supposed to take the KCPE. This exam was first established in 1985 to reflect the change in the Kenyan educational system from a 7-4-2-3 structure (seven years of primary, four years of lower secondary, two years of upper secondary, and three years of university) to an 8-4-4 structure (eight years of primary, four years of secondary, and four years of university). One result of this restructuring is that girls and boys are now expected to study the same subjects.

The KCPE exam consists of seven compulsory papers that are given equal weight: English; Kiswahili; Mathematics; Science and Agriculture; Geography, History, Civics, and Religion; Arts, Crafts, and Music; and Home Science and Business Education. Each student is given both a numerical score ranging from 0 to 700 and a letter grade that is standardized and ranges from $\mathrm{A}$ to $\mathrm{E}$ with the median between $\mathrm{C}$ and $\mathrm{C}+{ }^{5}$ Because the exam is meant to serve as a terminal qualification and not just as a means of determining selection into secondary school, it covers a broad range of material, much of which is designed to provide "practical" skills to children in rural areas (Appleton 1995).

Given the importance attached to the results, the exam would appear to structure the primary school curriculum. Indeed, the Ministry designates how much time is to be allotted to each subject in each Standard; despite the Ministry directive, two separate field studies found that time spent on particular subjects varied across schools (Appleton 1995). Because the exam requires that a large amount of material be covered and because many 
questions are knowledge-based, considerable premium would seem to be put on memorization skills. However, an early study of the correlates of exam performance found that analytic reasoning ability was "the psychological trait which it most tested" (See Bali et al. 1984, as cited in Appleton 1995). Moreover, a recent study found that students who performed well on Raven's Progressive Matrices, a test of nonverbal reasoning that is supposed to be independent of schooling, also performed well on the KCPE (Appleton 1995).

One important regulation that is set nationally and has implications for this study relates to pregnancy. The official Kenyan policy is that girls who become pregnant while in school must drop out temporarily. Although abortion is illegal, services are available. Girls who have access to these services and whose pregnancy is not detected by the school administration will be able to remain in school. Girls who give birth are not prohibited from returning to the same school, although it is not clear whether any schools permit reinstatement. As for boys, there is no equivalent Ministry regulation for those found to impregnate girls and thus each school is free to set its own policy.

\section{OUR Data on Primary SCHOOLS}

To explore the relationship between school quality and differential adolescent outcomes for boys and girls, we undertook a small-scale field study in rural areas of three districts in Kenya (Kilifi, Nakuru, and Nyeri) in May through August of 1996. A key feature of our study design is the linkage of school-based data with a population-based sample of both in-school and outof-school adolescents so that we can ultimately explore the implications of school quality for a broader range of educational and reproductive outcomes. 
The study was fielded in the summer of 1996 after extensive focus group work and pretesting with adolescents. For the purposes of this paper, we focus on preliminary findings from our school-based data, with an emphasis on results that contribute to a further understanding of gender differences in the primary school experiences of adolescents.

\section{Sampling strategy}

Because budget and time constraints precluded our visiting a representative sample of schools, we used a purposeful strategy to select the widest range of school environments in order to have some examples of the very best and the very worst, as well as the more typical, school situations in Kenya. The sampling strategy for the schools was designed in three stages.

The first stage was to select three of Kenya's 50 districts representing the range of school environments from the point of view of national examination results and of girls' participation in school. Using district rankings on $1993 \mathrm{KCPE}$ scores as well as primary and secondary enrollment rates for boys and girls, we selected Nyeri as reflecting the high end, Nakuru the middle, and Kilifi as the low end of the schooling spectrum.

The second stage was to select clusters from the national sampling frame, again to reflect the high, middle, and low end of the educational spectrum as measured by KCPE scores within each district. Based on KCPE performance, 12 clusters per district were then chosen for preliminary listing by the Central Bureau of Statistics (CBS) in geographically proximate (but, given the nature of the national sampling frame, not contiguous) groups of 3 4 clusters.

The third stage was to select specific clusters and schools from the CBS listings so as to maximize the overlap of adolescents from our community- 
based sample and schools. The constraints of our sampling budget allowed for 36 primary schools as well as a sample of 15 secondary schools (results not presented here). Choice of the specific primary schools to be visited was based on the goal of a minimum of 60 percent coverage of the school-going adolescents in each cluster. Our sample includes 10 primary schools in Kilifi and 13 each in Nakuru and Nyeri. ${ }^{6}$

\section{Research methodology}

This study, with its adaptation of situation analysis-a tool developed by the Population Council to evaluate functioning of family planning services through on-site visits to a large number of service delivery points-is, to our knowledge, the first of its kind. The primary schools in each geographic area were visited for two full days each and were assessed using five instruments. The data, which were collected via both observation and interview, provide a description of the quality of schooling in both quantitative and qualitative terms.

Within the family planning field, evaluation of service sites had often relied on expert opinion of those based in capital cities or was limited to interviews with community informants. Situation analysis is considered innovative because it involves clinic visits, and entails (1) interviews with managers, providers, and family planning clients, (2) detailed recording of clinic facilities, equipment, and commodities available on the day of the field team visit, and (3) nonparticipant direct observation of client-provider interactions. The survey instruments are designed to be comprehensive, enabling the researcher to describe the functioning of the clinics in detail and 
to assess the quality of services provided (Miller et al. 1997).

The motivation for situation analysis of schools parallels that for family planning clinics. The situation analysis includes observation of English and Math classes for Standards 7 and 8, an interview with the head teacher, interviews with those English and Math teachers who are observed, interviews with students, and observation of school facilities and of boy-girl interactions in hallways, lunchrooms, and near the toilets. In the classroom observation, we give special attention to the differential treatment of boys and girls by the teacher in both teacher- and student-initiated exchanges, following on the pioneering work of Sadker and Sadker (1995) in the United States.

Table 1 shows the five school-based instruments, their mode of administration, and the target number administered for each school. Each of these instruments is used to capture critical elements of the school environment. Student data collected from Standards 7 and 8 are used to characterize adolescents' collective experience in the school; classroom data are used to characterize experiences of adolescents in Standards 7 and 8 in two of the most important subjects-English and Math-in each school; and interviews with teachers observed in these classrooms are used to characterize the qualifications and attitudes of some of the most important teachers whom adolescents encounter in the school. Details on the data collected in each instrument are provided in the Appendix.

\section{Analytic strategy}

As already indicated, the primary schools in our sample are not representative of the underlying population of primary schools in Kenya. Instead, the districts and clusters in which the schools are located contain within them the range of schools available to Kenyan adolescents if evaluated 
according to average scores on the primary school leaving exams. Because some relevant features of adolescent schooling are common across our diverse sample of schools, we can conclude that these are situations that most adolescents experience. However, many other aspects of the school environment vary across schools. To the extent that these variations are associated with schooling outcomes, we will be able to identify potential avenues for further exploration and testing.

Table 1 Characteristics of school instruments

\begin{tabular}{|c|c|c|}
\hline Instrument & Mode of Administration & Number Per School \\
\hline Head Teacher & Interviewer Administered & 1 \\
\hline Teachers & Interviewer Administered & 2 Math, 2 English \\
\hline Students & Self-Administered & 30 Girls, 30 Boys \\
\hline Classroom Observation & Observation & 4 Math*, 4 English* \\
\hline $\begin{array}{l}\text { School Inventory \& } \\
\text { Observation }\end{array}$ & Observation & 1 \\
\hline \multicolumn{3}{|l|}{ * 2 classes per teacher } \\
\hline \multicolumn{3}{|c|}{$\begin{array}{l}\text { We have categorized our schools into two types: (1) high-performing } \\
\text { ols, those with high exam scores for girls, }{ }^{7} \mathrm{~N}=12 \text {, (2) low-performing } \\
\text { ols, those with low exam scores for girls, } \mathrm{N}=21 \text {. The cut point between } \\
\text { two groups is based on the percentage of girls scoring above B-. For } \\
\text { ya as a whole, approximately one-quarter of students score that well; thus } \\
\text { cut point used here to divide the schools into the two groups is .25. As }\end{array}$} \\
\hline
\end{tabular}


different districts can be meaningfully compared. All our results are presented according to this categorization scheme. ${ }^{8}$

As expected, students in the high-performing schools come from families that, for the most part, are better educated. Based on student reporting, we created an index measuring parental education, with a value of 0 when both parents have been to primary or less, .5 when one parent has been to secondary or more, and 1 when both parents have been to secondary or higher. ${ }^{9}$ The index averages .53 for high-performing schools and .37 for lowperforming schools, ranging from .11 to .74 for low-performing schools and from .27 to .75 for high-performing schools. Thus students from more educated families can be found in both high- and low-performing schools. Indeed, the correlation coefficient between parents' education and school performance is surprisingly low: .34 . Whenever we draw on qualitative data from the schools, we will identify the school by whether it is high- or lowperforming as well as high or low on parental education, defined according to whether the school falls above or below .51, the median of our parental education index.

With the exception of the teacher data, our unit of analysis in presenting the results from the situation analysis is the school. In the case of data drawn from instruments that are administered only once in each school, the analysis is straightforward. In the case of data drawn from multiple questionnaires or observations per school, the data are first aggregated to produce a schoolbased estimate before being aggregated again to present averages across schools by type of school. For example, the 12 high-performing schools contain a total of 749 students who filled out a student questionnaire, while the 21 low-performing schools contain 1,214 students; as a result our student- 
based results are robust. Because of the multiple sampling and analysis layers, conventional tests of statistical significance for differences between high- and low-performing schools are not appropriate. For the time being, we just present the averages. 


\section{SCHOOLING EXPERIENCES OF ADOLESCENTS}

In this section, we present the results of our study of Kenyan primary schools. We start with a short description of overall levels and patterns of enrollment in our sample clusters. Using our typology of "high" and "low" performing schools, we present both qualitative and quantitative data on school outcomes as well as various dimensions of school quality. School outcomes include KCPE performance, age for grade, attendance, and reproductive health knowledge. Dimensions of school quality include material inputs, opportunities to learn, teacher attitudes, school and classroom dynamics (including harassment), and family life education.

\section{School enrollment in the three districts}

Data from our preliminary household listing provide some background on overall school enrollment rates and gender differences across our three districts. Table 2 indicates that school attendance among adolescents varies within Kenya by location and age and, in two of three districts, by sex. While the majority of adolescents are currently in school, there is a large drop off in attendance by age through the teenage years. In addition, in Kilifi, adolescent girls are much less likely to be in school than are boys, especially in the older age groups; less than a third of girls aged 17-18 still attend school, compared with nearly one-half of boys.

The other noteworthy finding is that most older adolescents who are still in school attend primary school despite the fact that the expected age for primary school leaving is 14 (see Table 3). For this reason, we focus on the results from our primary school data because they best capture the school experience of the majority of school-going adolescents in Kenya. Table 3 also 
reveals considerable differentials by district, with the vast majority of schoolgoing 17-18-year-olds in Kilifi attending primary school, compared to about one-third of their counterparts in Nyeri.

Table 2 Percent of adolescents currently attending school, by age, sex, and district

\begin{tabular}{lcc|cc|cc} 
& \multicolumn{2}{c}{$\mathbf{1 2 - 1 4}$} & \multicolumn{2}{c}{$\mathbf{1 5 - 1 6}$} & \multicolumn{2}{c}{$\mathbf{1 7 - 1 8}$} \\
District & Male & Female & Male & Female & Male & Female \\
$\begin{array}{l}\text { Nyeri } \\
\text { (N=699) }\end{array}$ & 95 & 94 & 80 & 80 & 57 & 60 \\
$\begin{array}{l}\text { Nakuru } \\
\text { N=909) }\end{array}$ & 90 & 90 & 72 & 77 & 60 & 52 \\
$\begin{array}{l}\text { Kilifi } \\
(\mathrm{N}=1,237)\end{array}$ & 83 & 71 & 74 & 55 & 47 & 29 \\
\hline
\end{tabular}

Table 3 Percent of school-going adolescents currently attending primary school, by age and district

\begin{tabular}{lcccc}
\hline District & $\mathbf{1 2 - 1 4}$ & $\mathbf{1 5 - 1 6}$ & $\mathbf{1 7 - 1 8}$ & Total \\
\hline Nyeri (N=571) & 96 & 73 & 35 & 79 \\
Nakuru (N=710) & 98 & 71 & 41 & 81 \\
Kilifi (N=791) & 99 & 90 & 80 & 94 \\
\hline
\end{tabular}

\section{Performance, progress, and attendance in Kenyan schools}

We begin our description of the school data by exploring several outcomes. Table 4 presents data on exam performance, age, and attendance and indicates from which of the survey instruments each outcome is derived. For example, 41 percent of girls score B- and above on the KCPE exam in the 12 high-performing schools, whereas 11 percent score that well in the 21 lowperforming schools. As is the case for Kenya as a whole, boys in our sampled schools do better; 47 percent of boys score B- and above in the high- 
performing group, compared with 21 percent of boys in the low-performing group.

Table 4 Performance, progress, and attendance

\begin{tabular}{|c|c|c|c|}
\hline Description of Variable & Instrument & $\begin{array}{c}\text { Low- } \\
\text { Performing } \\
\text { Schools } \\
(\mathrm{N}=21)\end{array}$ & $\begin{array}{l}\text { High- } \\
\text { Performing } \\
\text { Schools } \\
(\mathrm{N}=12)\end{array}$ \\
\hline $\begin{array}{l}\text { KCPE Score } \\
\text { Boys scoring B- and above on } \\
\text { KCPE Exam }\end{array}$ & Head Teacher & $\begin{array}{c}\text { Percentage } \\
21\end{array}$ & $\begin{array}{c}\text { Percentage } \\
47\end{array}$ \\
\hline $\begin{array}{l}\text { Girls scoring B- and above on } \\
\text { KCPE Exam }\end{array}$ & Head Teacher & 11 & 41 \\
\hline $\begin{array}{l}\text { Age } \\
\text { Mean age of boys in Standard } 7\end{array}$ & Student & $\begin{array}{l}\text { Age } \\
14.8\end{array}$ & $\begin{array}{l}\text { Age } \\
14.8\end{array}$ \\
\hline Mean age of girls in Standard 7 & Student & 14.4 & 14.5 \\
\hline Mean age of boys in Standard 8 & Student & 15.5 & 15.4 \\
\hline Mean age of girls in Standard 8 & Student & 15.0 & 15.1 \\
\hline $\begin{array}{l}\text { Attendance } \\
\text { Average daily attendance of } \\
\text { boys in Standards } 7-8 \text { in week } \\
\text { preceding survey }\end{array}$ & Inventory & $\begin{array}{c}\text { Percentage } \\
90\end{array}$ & $\begin{array}{c}\text { Percentage } \\
94\end{array}$ \\
\hline $\begin{array}{l}\text { Average daily attendance of } \\
\text { girls in Standards } 7-8 \text { in week } \\
\text { preceding survey }\end{array}$ & Inventory & 93 & 95 \\
\hline
\end{tabular}

Given that approximately one-quarter of Kenyan students score B- and above on the KCPE, any school where more than 25 percent of students score B- and above is "better" than the average Kenyan school, and any school where fewer than 25 percent score B- and above is "worse" than the average. For our 36 schools, the percentage scoring B- and above ranges from 3 to 78 with a median of 23 percent, suggesting that, at least on this dimension, the sample is representative of Kenyan schools. ${ }^{10}$ 
As we indicated above, many adolescents are behind standard for their age because of delayed entry and grade repetition. If a child begins Standard 1 at six, the recommended age at entry, he or she would be 12-13 in Standard 7 and 13-14 in Standard 8 if promoted each year. For the schools in our sample the mean age in Standard 7 as reported by students ranges from 13.1 to 16.1 with a median of 14.5. ${ }^{11}$ Interestingly, the mean age in Standard 8 is 15.3 with a range from 13.7 to 16.3 , that is, students do not age a year in going from Standard 7 to Standard 8. This finding is not unexpected, as the highest rate of dropping out occurs during this year (Makau 1994) and those who drop out are presumably older for their standard. However, mean age in Standards 7 and 8 does not vary by performance level of the school. There is, on the other hand, a pattern across all schools; for both standards, girls are younger than boys, perhaps because parents are more willing to pay for another year of school for their sons, indeed may encourage grade repetition in the belief, evidently mistaken, that it will increase the likelihood of passing the KCPE. ${ }^{12}$ In Standard 7 the median age of boys for our sample of schools is 14.8 whereas for girls it is 14.4. In Standard 8, the median is 15.5 for boys and 15.1 for girls. Thus girls who drop out of primary school do so at a younger age than boys.

The attendance rate is another outcome that we thought would reveal differences between boys and girls; however, there appears to be little variability in attendance levels between schools and, within schools, between boys and girls. Indeed, our data suggest a very high level of attendance for Standards 7 and 8 in the week prior to our field team visits, with 28 of 36 schools having rates above 90 percent. The rates for the low- and highperforming schools are 91 and 95 percent, respectively. Given that the field team supervisors frequently commented about student absences due to unpaid 
fees $^{13}$ and mentioned the poor quality of school records, we doubt whether these attendance data, provided by the head teacher, are reliable.

There are several other important school outcomes for which data are lacking or for which the interpretation is ambiguous. For example, it appears that schools do not maintain accurate records on numbers withdrawing and reasons for withdrawal. Thus it is not possible to determine whether a girl has left school because of pregnancy. In addition, promotion rates from grade to grade would appear to be important. Yet policies for promotion vary, with some high-performing schools having low promotion rates because the less capable students are held back so as to keep KCPE exam scores high. ${ }^{14}$ In contrast, weaker schools may have higher promotion rates due to less stringent promotion requirements. Finally, in some schools promotion may depend on timely payment of school fees, which is difficult for many parents.

\section{Various dimensions of school quality}

In selecting which dimensions of school quality to present, our criterion for inclusion was that the dimension might affect girls and boys differently or might be differentially available to them.

Material inputs. As our literature review indicated, various material inputs are thought to affect school quality, including the availability of basic amenities, the presence of instructional materials, access to and quality of basic facilities, and curriculum beyond the core. We are interested in inputs that might have a disproportionate impact on girls' attendance and performance at school or in those to which girls might have limited access. In Table 5 we present data on water and toilet facilities, sports facilities, and textbooks. 
It is possible that the quality of water and toilet facilities might affect adolescent girls more than boys because of menstruation. Given the average length of a Kenyan school day - approximately eight hours ${ }^{15}$ - the adolescent girl who has her period may want to change her sanitary pads or cotton wool and may need water to wash her hands and a garbage can to dispose of soiled pads or cotton wool. ${ }^{16}$ While girls who attend high-performing schools are much more likely to have water on the premises - 67 percent of these schools have water compared to 38 percent of low-performing schools-the toilet facilities are equally inadequate in both groups. Many are neither clean, functional, nor secure from observation. According to our data, 48 percent of girls' toilets are clean in low-performing schools and 25 percent in highperforming schools, with clean defined generously as "more than half of the facilities in good order, some stains, small amount of litter."

Not one school visited had a separate disposal facility for sanitary pads or cotton wool; presumably if girls needed to dispose of these, they threw them down pit latrines. Only 14 percent of girls' toilets are secure from observation in low-performing schools. The high-performing schools do not fare any better, with 17 percent being sufficiently private. Our field teams were instructed to spend time near the toilets at each break and at lunch time on each day of the 2-3-day school visit. Boys were observed hanging around girls' toilets in 14 percent of low-performing schools and 58 percent of highperforming schools. The field supervisors were explicit about the state of the toilets in their data collection notes. 
Table 5 Material inputs to school quality

\begin{tabular}{|c|c|c|c|}
\hline Description of Variable & Instrument & $\begin{array}{c}\text { Low- } \\
\text { Performing } \\
\text { Schools } \\
(\mathrm{N}=21)\end{array}$ & $\begin{array}{c}\text { High- } \\
\text { Performing } \\
\text { Schools } \\
(\mathbf{N}=12)\end{array}$ \\
\hline $\begin{array}{l}\text { Water } \\
\text { Water at school }\end{array}$ & Inventory & $\begin{array}{c}\text { Percentage } \\
38\end{array}$ & $\begin{array}{c}\text { Percentage } \\
67\end{array}$ \\
\hline $\begin{array}{l}\text { Toilets } \\
\text { Girls' toilet clean } \\
\text { Place to wash menstrual rags } \\
\text { Disposal facility for sanitary } \\
\quad \text { napkins/ towels } \\
\text { Barrier between girls' toilets } \\
\text { Toilets secure from observation } \\
\text { Boys observed hanging around } \\
\quad \text { girls' toilets }\end{array}$ & $\begin{array}{l}\text { Inventory } \\
\text { Inventory } \\
\text { Inventory } \\
\text { Inventory } \\
\text { Inventory } \\
\text { Inventory }\end{array}$ & $\begin{array}{c}48 \\
0 \\
\\
0 \\
67 \\
14 \\
14\end{array}$ & $\begin{array}{c}25 \\
0 \\
\\
0 \\
83 \\
17 \\
\\
58\end{array}$ \\
\hline $\begin{array}{l}\text { Sports Facilities } \\
\text { Hours field used per day } \\
\text { By boys } \\
\text { By girls } \\
\text { Number of sports played } \\
\text { By boys } \\
\text { By girls } \\
\end{array}$ & $\begin{array}{l}\text { Inventory } \\
\text { Inventory } \\
\text { Inventory } \\
\text { Inventory }\end{array}$ & $\begin{array}{c}\text { Number } \\
2.1 \\
2.3 \\
\\
2.2 \\
3.0 \\
\end{array}$ & $\begin{array}{c}\text { Number } \\
\\
2.3 \\
2.7 \\
\\
2.3 \\
3.2 \\
\end{array}$ \\
\hline $\begin{array}{c}\text { Field use after school } \\
\text { By boys } \\
\text { By girls }\end{array}$ & $\begin{array}{l}\text { Inventory } \\
\text { Inventory }\end{array}$ & $\begin{array}{c}\text { Percentage } \\
48 \\
43 \\
\end{array}$ & $\begin{array}{c}\text { Percentage } \\
25 \\
17 \\
\end{array}$ \\
\hline $\begin{array}{l}\text { Textbooks } \\
\text { Observed having text } \\
\text { Boys/Math \& English } \\
\text { Girls/Math \& English } \\
\text { Boys/Math only } \\
\text { Girls/Math only } \\
\text { All recommended texts } \\
\text { Boys } \\
\text { Girls }\end{array}$ & $\begin{array}{c}\text { Observation } \\
\text { Observation } \\
\text { Observation } \\
\text { Observation } \\
\\
\text { Student } \\
\text { Student } \\
\end{array}$ & $\begin{array}{l}44 \\
50 \\
47 \\
55\end{array}$ & $\begin{array}{l}38 \\
40 \\
47 \\
53\end{array}$ \\
\hline
\end{tabular}


"Their toilet facilities are so wasted and filthy. The toilets don't have doors and roofs and look like they are just about to collapse. The girls' toilets are covered by papers to avoid them being seen through the timber wall. The toilets are just next to each other. Most students prefer to run down the valley to relieve themselves than use the toilets. The girls are the most affected as they have to go into the filthy toilets while the boys just stand at the door and relieve themselves." (Low parental education, high-performing school)

"The toilets of this school are in a state of disrepair. The boys stand at the door and urinate while the girls are forced to go in. The wooden planks (the floor) look like they could give way anytime." (High parental education, high-performing school)

“The boys' school toilet is just after the girls' toilet. The deputy head teacher said they have now completed a new toilet for boys because they're mischievous to girls in or near the toilet. When pressed further to explain he said boys are 'cheeky' with the girls close to the toilet." (Low parental education, low-performing school)

Given the state of the toilets, adolescent schoolgirls in Kenya are hardly likely to expect anything better and appear to make do with what they have; only 5 percent of girls claim to have stayed away from school the last time they had their period. While improving these facilities may not affect exam performance, it would certainly make life at school better for students.

Increasing emphasis is being put on girls' participation in sports, not only for the physical payoff but also for its potential social and emotional benefit. Given the generally inferior athletic facilities available to women worldwide (International Council for Health, Physical Education, Recreation, Sport and Dance 1996), we expected that girls would be less likely to participate in sports. However, our measures of girls' access to sports 
facilities suggest that, in primary schools, girls are at least as likely as boys to participate. Three indices, which measure the number of hours fields are used during the school day, the sports played, and the percentage of schools where fields are used after school, indicate a small advantage for girls, with the highperforming schools doing slightly better and the low-performing doing slightly better on use after school. The slight advantage for girls is entirely a result of the widespread availability in Kenyan schools of netball, a sport played only by girls that is common in Britain and its former colonies and requires less space than other sports. ${ }^{17}$

Girls and boys should benefit equally from textbooks. Yet there is a question of whether girls are as likely to have them as boys, especially when schools do not provide them but require that they be purchased. Given that parents may be more willing to invest in their sons' schooling, girls may be at a disadvantage. We measured access to textbooks in two ways. First, we observed whether girls and boys had the textbook being used in the classes observed; second, we asked students whether they had all the required texts. Regardless of which measure is used, we found no relationship between textbook access and sex of the student; if anything, girls had a slight advantage. Neither girls nor boys had a full set of the recommended textbooks: only 16 percent of students had all recommended texts in highperforming schools and 11 percent in low-performing schools. In the Mathematics classes observed, where presumably a text would be critical to performance, approximately half of the students had the text.

In sum, with regard to the material inputs measured here, girls do not appear to be at a disadvantage relative to boys. What is most striking is that, with the exception of access to water, high-performing schools are not better off than low-performing schools. 
Opportunities to learn. We label opportunities to learn those variables that capture, whether directly or not, the amount of time devoted to learning. Although there is no reason to think that girls suffer disproportionately from a chaotic learning environment, the field supervisors' comments contain numerous references to the disorganized nature of many schools visited, and these characterizations applied to both high- and low-performing schools as well as to schools with more and less educated parents. Frequently head teachers were absent when the data collection teams arrived and were reported to be away at meetings, tending to personal business, or going to funerals. Moreover, classroom teachers were often absent or late and classes were rescheduled, doubled up, or taught by other teachers.

As with material inputs, the factors we consider here have a potential gender dimension or effect. These include time devoted to chores, homework, and punishment, as well as class size, including distribution of boys and girls (see Table 6).

Chores performed at school, particularly if more domestic in nature, may take away from time devoted to learning. The literature we reviewed contains anecdotal accounts of girls doing more duties at school than boys, mirroring their presumably greater responsibilities in the home. We provided students with a list of duties. Some of these were more menial in nature, including preparing and serving food, running errands, and assisting teachers 
Table 6 Opportunities to learn

\begin{tabular}{|c|c|c|c|}
\hline Description of Variable & Instrument & $\begin{array}{c}\text { Low- } \\
\text { Performing } \\
\text { Schools }(\mathrm{N}=21)\end{array}$ & $\begin{array}{l}\text { High-Performing } \\
\text { Schools } \\
(\mathrm{N}=12)\end{array}$ \\
\hline $\begin{array}{l}\text { Duties reported on previous day } \\
\text { Menial chores } \\
\text { Boys } \\
\text { Girls } \\
\text { Prefect/teacher assistant } \\
\text { Boys } \\
\text { Girls }\end{array}$ & $\begin{array}{l}\text { Student } \\
\text { Student } \\
\text { Student } \\
\text { Student }\end{array}$ & $\begin{array}{c}\text { Percentage } \\
64 \\
73 \\
\\
12 \\
7 \\
\end{array}$ & $\begin{array}{c}\text { Percentage } \\
69 \\
81 \\
\\
8 \\
5\end{array}$ \\
\hline $\begin{array}{l}\text { Homework } \\
\text { Spent }>30 \text { minutes on previous school day } \\
\text { Boys } \\
\text { Girls }\end{array}$ & $\begin{array}{l}\text { Student } \\
\text { Student }\end{array}$ & $\begin{array}{l}56 \\
61\end{array}$ & $\begin{array}{l}60 \\
70 \\
\end{array}$ \\
\hline $\begin{array}{l}\text { Students tutored in previous week } \\
\text { Boys } \\
\text { Girls }\end{array}$ & $\begin{array}{l}\text { Student } \\
\text { Student }\end{array}$ & $\begin{array}{l}44 \\
40 \\
\end{array}$ & $\begin{array}{l}23 \\
39 \\
\end{array}$ \\
\hline $\begin{array}{l}\text { Punishment } \\
\text { Received any punishment on previous school day } \\
\text { Boys } \\
\text { Girls } \\
\text { Type of punishment received* } \\
\text { Assigned extra duties } \\
\text { Boys } \\
\text { Girls } \\
\text { Assigned extra school work } \\
\text { Boys } \\
\text { Girls } \\
\text { Caned/hit } \\
\text { Boys } \\
\text { Girls }\end{array}$ & $\begin{array}{l}\text { Student } \\
\text { Student } \\
\text { Student } \\
\text { Student } \\
\text { Student } \\
\text { Student } \\
\text { Student } \\
\text { Student }\end{array}$ & $\begin{array}{l}26 \\
27 \\
\\
2 \\
3 \\
\\
2 \\
7 \\
\\
17 \\
13\end{array}$ & $\begin{array}{c}16 \\
12 \\
\\
\\
1 \\
3 \\
\\
2 \\
3 \\
\\
10 \\
6\end{array}$ \\
\hline $\begin{array}{l}\text { Reason for Punishment* } \\
\text { Didn't finish homework } \\
\text { Boys } \\
\text { Girls } \\
\text { Performed badly on test or in class } \\
\text { Boys } \\
\text { Girls } \\
\text { Spoke without permission } \\
\text { Boys } \\
\text { Girls }\end{array}$ & $\begin{array}{l}\text { Student } \\
\text { Student } \\
\text { Student } \\
\text { Student } \\
\text { Student } \\
\text { Student }\end{array}$ & $\begin{array}{l}4 \\
7 \\
\\
7 \\
5 \\
\\
\\
4 \\
4\end{array}$ & $\begin{array}{l}4 \\
4 \\
\\
5 \\
3 \\
\\
\\
2 \\
3\end{array}$ \\
\hline $\begin{array}{l}\text { Sex Ratio } \\
\text { Boys to girls Standard } 7 \\
\text { Boys to girls Standard } 8\end{array}$ & $\begin{array}{l}\text { Head Teacher } \\
\text { Head Teacher }\end{array}$ & $\begin{array}{c}\text { Ratio } \\
1.1 \\
1.5\end{array}$ & $\begin{array}{c}\text { Ratio } \\
0.8 \\
1.0\end{array}$ \\
\hline Class Size & Observation & $\begin{array}{c}\text { Number } \\
36\end{array}$ & $\begin{array}{c}\text { Number } \\
36\end{array}$ \\
\hline
\end{tabular}

* Percentages listed under the headings "Type of Punishment Received" and "Reason for Punishment" do not respectively equal the total of all students who "Received Any Punishment on Previous School Day." Other answers given by respondents under these headings were deemed too small to be worth including. 
in their homes. Two were more academic - assisting teachers with younger students, and working as a monitor or prefect-for which assignment to do them is presumably based on school performance. We then asked students to indicate which they did yesterday or the previous school day. A greater percentage of girls, slightly more in high- than low-performing schools, do menial chores than boys. Moreover, girls are slightly less likely than boys to do those duties designated for the better students.

If girls do have more domestic responsibilities than boys, they may have less time for homework. On the other hand, if girls are confined to home after school and boys are allowed more freedom, girls may use some of their free time to do more homework. Given that systematic information on adolescent time use and mobility is virtually nonexistent for developing countries, a case could be made for either scenario. ${ }^{18}$ According to students' self-reports, girls do slightly more homework than boys. The difference is greatest in highperforming schools, where 70 percent of girls did more than 30 minutes of homework the day before the interview compared to 60 percent of boys.

In many developing countries, tutoring has become a major industry, with underpaid teachers supplementing their salaries by coaching students for exams after school. If parents are more willing to invest in their sons than their daughters, tutoring may be more common among boys. However, if tutoring is more prevalent among weaker students, and girls have more academic difficulties, then tutoring may be more widespread among girls. We asked students whether, during the week prior to the interview, they were "given private tuition in any subject by private arrangement." The results indicate considerable numbers of students being tutored. While virtually the same percentages of girls and boys are tutored in low-performing schools, girls are more likely to be tutored in high-performing schools, which may 
account for their better performance.

We have also included punishment under opportunities to learn because time spent reprimanding or hitting students, whether for good cause or not, is time that detracts from teaching. While our classroom observers saw very few teachers disciplining students in class, reflecting the fact that students and teachers were on their best behavior with an outsider present, substantial numbers of students, when interviewed, report being disciplined. Moreover, the observers saw punishment outside of classes, perhaps when no one thought they were looking. The supervisors' comments about caning reveal, in some cases, a certain amount of brutality taking place at school:

"The school is run by the cane. Students get caned for small offenses or at times, like we witnessed, for no reason at all. For example, a boy was being punished by one teacher so as he stood up to go another teacher grabbed him and started caning him and then another." (Low parental education, low-performing school)

"This school is also ruled by the cane. Both boys and girls, but especially boys, are really caned. Someone could be caned continuously for as long as 10 minutes and they walk out limping, not being able to walk properly. One teacher was heard saying 'you boy come here, you owe me some strokes. I was meant to cane you last week.' This caning makes the students so fearful that it is impossible to see them making a mistake or even teasing the girls.... The head teacher says that students are punished in school even for offenses committed out of school; if it is proved, they are caned and caned severely." (Low parental education, low-performing school)

"As usual, like in most Nakuru rural schools, the school is run by the cane. Students are caned severely for minor offenses and for getting low marks. The girls are caned on the thighs and hands. The students are so tense that when they see teachers passing, you can just see fear in their eyes." (High parental education, highperforming school) 
The classroom observers also commented about punishment:

"Three girls were missing writing materials. The teacher knocked their heads as a punishment for forgetting books at home. She promised to 'deal' with them after the class." (High parental education, low-performing school)

"Two girls were hit on their heads by the teacher using a biro [pen]. He promised to deal with them when the 'visitor' left." (High parental education, low-performing school)

"All the students put up their hands claiming to have done it [the homework] but upon checking the teacher discovered that some were lying. He pinched one girl on the arm, then remembered I was there, looked at me quickly, and stopped checking on the homework." (High parental education, low-performing school)

"Only two boys had done an exercise she asked them to attempt for homework the previous day. She was very annoyed and told them that the only reason why she did not punish them was because there was a visitor in the class. She said 'otherwise, you know what would have happened. But she [the observer] will go and then we will sort this out.' "(High parental education, lowperforming school)

Over one-fifth of boys and girls indicated they were punished on the previous school day, with more students punished in low- than highperforming schools. There is no difference between boys and girls in the percentage reporting punishment in low-performing schools and only a slight difference in high-performing schools. This was somewhat surprising, as boys are generally thought to be less well behaved than girls (AndersonLevitt, Bloch, and Soumare, forthcoming). However, as the observers' reports affirm, punishment is not just for breaking school rules or misbehaving in class, but also for academic difficulties, and girls did not perform as well as boys. The principal reasons students report for being disciplined are performing badly in class or on a test, not finishing homework that had been 
assigned, or speaking in class without being called on by the teacher. The primary form of discipline was caning or hitting. Girls were more likely to be given extra duties or school work; yet even for them, punishment was much more likely to be corporal, with 13 percent of girls in low-performing schools indicating they were caned on the previous school day and 6 percent in highperforming schools.

While the final set of variables in this section-class sex ratio and size- are not strictly measures of time devoted to instruction, they may affect other aspects of the "opportunity to learn." There is some evidence, as the literature review indicated, that girls function better in single-sex schools while boys do better in mixed schools. However, we know of no study in a developing-country setting that examines whether the sex ratio in mixed schools affects girls' performance. Our data suggest that where there are more girls relative to boys, girls indeed fare better, perhaps because they feel more comfortable or because the atmosphere is more conducive to learning. The sex ratios also indicate that there are fewer girls relative to boys in Standard 8 than in Standard 7. This finding is expected since nationally girls are more likely to drop out prior to taking the KCPE exam (Makau 1994). Moreover, dropping out for girls appears to be more common in the low-performing schools.

Class size is included here because, theoretically, the more students in a class, the less time the teacher can devote to each student. We also thought that, given the supposed passivity of girls, class size might affect their performance more than that of their male peers. While the number of girls relative to boys apparently affects girls' academic achievement, absolute numbers appear not to matter, a finding in accordance with earlier studies (Lockheed and Verspoor et al. 1991). On average, the number of students in 
classes observed by our field workers is the same in high- and low-performing schools. If most of class time is devoted to lecture or group response to teachers' questions (see below), then it is not unexpected that the number of students is irrelevant for academic performance.

In contrast to the material inputs reviewed above, the factors we consider under opportunities to learn-chores, homework, tutoring, punishment, sex ratio, and class size-have slightly different effects on girls and boys, particularly in high-performing schools. Despite the fact that they constitute a greater proportion of the student body, girls do more homework, do more menial chores, get caned less, and are less likely to be assigned tasks for which selection is based on academic performance.

School and classroom dynamics. Included in the school and classroom dynamics category are variables that reflect day-to-day life in the classroom and the school at large, namely teacher attitudes and behavior, as well as interactions among students, and between teachers and students. We had hoped that classroom observation would be particularly revealing for this set of variables; it was not as successful as we had expected. Many teachers were uneasy about being observed and were convinced, despite the best efforts of our field teams, that they were being inspected. As was clear from comments teachers made in class about student punishment and from the difference between student reports of punishment and punishment observed, what we saw was atypical. Observation outside classes, where fieldworkers were less obtrusive, appears to have been more successful, especially in exposing the negative attributes of schools.

Teacher behavior. In our sample of Kenyan schools, as in most 
developing-country schools that have been investigated, the principal mode of teaching is to lecture using the blackboard or to rapidly fire questions at students where an individual or group response is expected. Largely absent is the kind of free-floating discussion common in many Western classrooms, where students are at liberty to challenge each other and the teacher. There has been some suggestion in the literature that girls learn best in a cooperative environment in which students share information and help one another (Sadker and Sadker 1995). Although we asked our observers to indicate whether any class time was allocated to group work, almost no instances were noted (see Table 7). Indeed, Fuller and Sayder's aptly named "chalk and talk" approach was universally observed in our sampled classrooms (data not shown).

In addition to asking our observers to indicate how class time was allocated, we also asked them to mark down each interaction between a student and teacher and to determine its nature. Our goal was to assess whether teachers pay more attention to boys and provide them with more encouragement or whether they treat girls and boys equitably. In constructing variables to measure "good interactions," we tried to include all events recorded by our observers that had a positive or supportive tone-or, at least, 
Table 7 School and classroom dynamics - teacher behavior

\begin{tabular}{|c|c|c|c|}
\hline Description of Variable & Instrument & $\begin{array}{l}\text { Low- } \\
\text { Performing } \\
\text { Schools } \\
(\mathbf{N}=\mathbf{2 1})\end{array}$ & $\begin{array}{l}\text { High- } \\
\text { Performing } \\
\text { Schools } \\
(\mathrm{N}=12)\end{array}$ \\
\hline $\begin{array}{l}\text { Class time } \\
\text { Class time devoted to group work }\end{array}$ & Observation & $\begin{array}{c}\text { Percentage } \\
0 \\
\end{array}$ & $\begin{array}{c}\text { Percentage } \\
0 \\
\end{array}$ \\
\hline $\begin{array}{l}\text { Student/Teacher Interaction } \\
\text { Good events* } \\
\text { Involving boys } \\
\text { Involving girls }\end{array}$ & $\begin{array}{l}\text { Observation } \\
\text { Observation }\end{array}$ & $\begin{array}{c}\text { Number } \\
15.7 \\
15.2\end{array}$ & $\begin{array}{c}\text { Number } \\
14.9 \\
11.4 \\
\end{array}$ \\
\hline $\begin{array}{l}\text { Student Report of Teacher Behavior } \\
\text { Teacher discouragement } \\
\text { Reported by boys } \\
\text { Reported by girls } \\
\text { Equal treatment } \\
\text { Reported by boys } \\
\text { Reported by girls }\end{array}$ & $\begin{array}{l}\text { Student } \\
\text { Student } \\
\text { Student } \\
\text { Student }\end{array}$ & $\begin{array}{c}\text { Percentage } \\
\\
16 \\
16 \\
\\
84 \\
87\end{array}$ & $\begin{array}{c}\text { Percentage } \\
\qquad \begin{array}{c}12 \\
8 \\
\\
84 \\
89\end{array}\end{array}$ \\
\hline $\begin{array}{l}\text { Receipt of Academic Prizes } \\
\text { Boys } \\
\text { Girls }\end{array}$ & $\begin{array}{l}\text { Head Teacher } \\
\text { Head Teacher }\end{array}$ & $\begin{array}{l}8 \\
4\end{array}$ & $\begin{array}{l}9 \\
4\end{array}$ \\
\hline
\end{tabular}

* Because the duration of classes and the composition of classes by sex vary, we adjusted the number of good events to a "standard" class of 40 minutes in duration with 20 students of each sex.

those that did not have a negative one. Thus, we included instances of students reading aloud; students making presentations in front of the class; teachers instructing or explaining; teachers acknowledging, extending, amplifying, or praising correct answers; teachers completing, explaining, or seeking responses to student questions; and teachers positively acknowledging, expanding upon, or encouraging student comments. While teachers have more good interactions with boys than with girls in both lowand high-performing schools, what is puzzling is that there are fewer good interactions with students in high-performing schools, particularly for girls. That the data on student-teacher interaction are not particularly revealing is undoubtedly attributable to the pedagogical style in Kenyan schools. This is similar to the situation in Togo, where the classroom dynamic has been 
characterized by the absence of "direct communication [which] limits teacher/student interactions of any kind" (Biraimah 1980: S207).

Our observers' comments about what they saw and heard are perhaps more revealing of underlying attitudes toward girls than of the behaviors they tried to quantify:

"The teacher told girls that they can never be household heads. This was prompted by the one girl who could not read the comprehension loudly and clearly." (High parental education, high-performing school)

"Most questions were directed to boys and not girls. The teacher told the girls that if they do not improve, he could foresee them joining the local Mathenge technical institute instead of good boarding schools or institutions... The teacher constantly told the class that the girls do not use common sense and that is why they might not make good sales persons. "Lazy salesmen like some of you girls get very little commission,' the teacher told the class." (High parental education, low-performing school)

" 'Some of you girls are shamelessly writing the wrong answers as if you are blind,' the teacher lamented." (High parental education, low-performing school)

"When the girls gave wrong answers the teacher was very unhappy and pointed out that 'girls do not understand because they do not use their heads.' When marking the exercise, the teacher concentrated in [sic] showing girls examples he had already written on the board. When I inquired about the extra attention, the teacher said that girls in 8A are weak and lazy." (High parental education, low-performing school)

"One class was reading a play and different students were assigned different roles. The play was about a young girl who had been abducted and beaten by a young man that her parents had chosen to marry her, but whom she had rejected. She then brings this young man to court and the play is about the hearing of the court case. The thing that struck me most about this case is that 
first of all the girl appeared helpless and the prosecutor even accused her of having gone to the young man's house willingly [implying that if this was true, then she deserved the beating]. Another thing that struck me was that the only female characters were Rukia [the girl who was abducted], her mother, and a witness. Their parts were very short. However, the teacher chose boys for the parts of the magistrate, court clerk, prosecutor, and policeman. When the teacher asked for volunteers for the part of policeman, a girl put her hand up and the teacher asked, 'Can you be a policeman? You do not have a commanding voice.' This did not make sense because the boy he chose sounded more or less like the girl he had rejected." (High parental education, lowperforming school)

"The bell ringer was a boy. In all the schools we went to, the bell ringers were boys." (High parental education, low-performing school)

"There was a group of girls sitting near the door who were quiet throughout the lessons, and she [the teacher] kept pointing at them and saying 'let sleeping dogs lie.' She never attempted to direct questions at them." (High parental education, low-performing school)

We also asked students how teachers acted toward them, specifically whether teachers discouraged them from studying certain subjects or pursuing careers, and whether boys and girls are treated equally at school. Although reported levels of discouragement are low, both boys and girls indicate less discouragement in high-performing schools. In high-performing schools boys report being discouraged slightly more than girls. As for equitable treatment, by and large students of both sexes feel that boys and girls are dealt with the same at school. Whether that is the case, or whether the notion of equitable treatment between the sexes is so alien that the question simply did not measure what we intended, cannot be determined. However, our observers, who were given a short gender training course prior to the fieldwork, noted a 
number of episodes where teachers maligned or were uncharitable toward girls. Furthermore, the awarding of academic prizes appears to be biased in favor of boys. While we would expect boys to earn twice as many prizes as girls in low-performing schools, where approximately twice as many boys score higher than $\mathrm{B}-$ on the KCPE, there should be little difference in the distribution of prizes in high-performing schools. Yet 9 percent of boys in high-performing schools earned prizes, compared to 4 percent of girls.

While there is evidence that girls learn better in single sex-schools, there has been less attention to whether performance of girls is enhanced when there are more female teachers. Our data indicate that the ratio of male to female teachers is highest in low-performing schools. Indeed there are over two times (2.3: 1) as many male teachers as female teachers in low-performing schools and nearly even numbers (1.3:1) of male and female teachers in highperforming schools. ${ }^{19}$ As we are not aware of any systematic selectivity in assignment of teachers to schools, we investigated, through an examination of answers to attitudinal questions, what it is about the presence of more women that may account for better performance among girls (see Table 8 ). ${ }^{20}$

Teacher credentials. In examining teacher credentials and attitudes we have chosen to report the results with the teacher, as opposed to the school, as the unit of analysis in part because the gender composition of the teacher sample in each school may not be representative of the actual gender makeup of teachers at that school. Moreover, the number of teachers sampled is small, 
Table 8 School and classroom dynamics - teacher credentials and attitudes

\begin{tabular}{|c|c|c|c|c|c|}
\hline \multirow[t]{2}{*}{ Description of Variable } & \multirow[t]{2}{*}{ Instrument } & \multicolumn{2}{|c|}{$\begin{array}{c}\text { Low-Performing } \\
\text { Schools }\end{array}$} & \multicolumn{2}{|c|}{ High-Performing Schools } \\
\hline & & $\begin{array}{c}\text { Male } \\
(\%)\end{array}$ & $\begin{array}{c}\text { Female } \\
(\%)\end{array}$ & $\begin{array}{c}\text { Male } \\
(\%)\end{array}$ & $\begin{array}{c}\text { Female } \\
(\%)\end{array}$ \\
\hline Teacher Credentials & & $(\mathrm{N}=60)$ & $(\mathrm{N}=21)$ & $(\mathrm{N}=30)$ & $(\mathrm{N}=16)$ \\
\hline Teacher $<$ P1 level & $\begin{array}{c}\text { Teacher/ } \\
\text { Head Teacher }\end{array}$ & 12 & 19 & 17 & 0 \\
\hline Teacher $=$ P1 level & $\begin{array}{c}\text { Teacher/ } \\
\text { Head Teacher }\end{array}$ & 77 & 76 & 70 & 81 \\
\hline Teacher $>$ P1 level & $\begin{array}{c}\text { Teacher/ } \\
\text { Head Teacher }\end{array}$ & 12 & 5 & 13 & 19 \\
\hline $\begin{array}{l}\text { Teacher Attitudes Toward } \\
\text { Gender of Students }\end{array}$ & & & & & \\
\hline Prefers teaching boys & Teacher & $\begin{array}{c}(\mathrm{N}=54) \\
17\end{array}$ & $\begin{array}{c}(\mathrm{N}=21) \\
43\end{array}$ & $\begin{array}{c}(\mathrm{N}=28) \\
21\end{array}$ & $\begin{array}{c}(\mathrm{N}=16) \\
19\end{array}$ \\
\hline Prefers teaching girls & Teacher & 2 & 5 & 7 & 0 \\
\hline No preference & Teacher & 81 & 52 & 71 & 81 \\
\hline $\begin{array}{l}\text { Teacher Attitudes Toward } \\
\text { Subjects }\end{array}$ & & $(\mathrm{N}=60)$ & $(\mathrm{N}=21)$ & $(\mathrm{N}=30)$ & $(\mathrm{N}=16)$ \\
\hline English important & & & & & \\
\hline For boys & Teacher/ & 67 & 52 & 67 & 88 \\
\hline For girls & $\begin{array}{c}\text { Teacher/ } \\
\text { Head Teacher }\end{array}$ & 68 & 57 & 70 & 88 \\
\hline Math important & & & & & \\
\hline For boys & $\begin{array}{c}\text { Teacher/ } \\
\text { Head Teacher }\end{array}$ & 80 & 48 & 73 & 81 \\
\hline For girls & $\begin{array}{c}\text { Teacher/ } \\
\text { Head Teacher }\end{array}$ & 72 & 38 & 67 & 75 \\
\hline English easier & & & & & \\
\hline For boys & $\begin{array}{c}\text { Teacher/ } \\
\text { Head Teacher }\end{array}$ & 3 & 5 & 7 & 0 \\
\hline For girls & $\begin{array}{c}\text { Teacher/ } \\
\text { Head Teacher }\end{array}$ & 45 & 57 & 50 & 69 \\
\hline Math easier & & & & & \\
\hline For boys & $\begin{array}{c}\text { Teacher/ } \\
\text { Head Teacher }\end{array}$ & 68 & 62 & 67 & 69 \\
\hline For girls & $\begin{array}{c}\text { Teacher/ } \\
\text { Head Teacher }\end{array}$ & 0 & 0 & 0 & 0 \\
\hline
\end{tabular}




\begin{tabular}{|c|c|c|c|c|c|}
\hline \multirow[t]{2}{*}{ Description of Variable } & \multirow[t]{2}{*}{ Instrument } & \multicolumn{2}{|c|}{$\begin{array}{c}\text { Low-Performing } \\
\text { Schools }\end{array}$} & \multicolumn{2}{|c|}{$\begin{array}{c}\text { High-Performing } \\
\text { Schools }\end{array}$} \\
\hline & & $\begin{array}{c}\text { Male } \\
(\%)\end{array}$ & $\begin{array}{c}\text { Female } \\
(\%)\end{array}$ & $\begin{array}{c}\text { Male } \\
(\%)\end{array}$ & $\begin{array}{c}\text { Female } \\
(\%)\end{array}$ \\
\hline $\begin{array}{l}\text { Teacher Attitudes Toward } \\
\text { Schoolgirl Pregnancy and } \\
\text { Teacher Having Sex } \\
\text { Pregnant girls should be forced to } \\
\text { leave school } \\
\text { Boys who make girls pregnant } \\
\text { should be expelled } \\
\text { Girls should be allowed to return to } \\
\text { same school after delivery }\end{array}$ & $\begin{array}{c}\text { Teacher/ } \\
\text { Head Teacher } \\
\text { Teacher/ } \\
\text { Head Teacher } \\
\text { Teacher/ } \\
\text { Head Teacher }\end{array}$ & $\begin{array}{c}(\mathrm{N}=60) \\
80 \\
13 \\
33\end{array}$ & $\begin{array}{c}(\mathrm{N}=21) \\
81 \\
5 \\
14\end{array}$ & $\begin{array}{c}(\mathrm{N}=30) \\
87 \\
10 \\
20\end{array}$ & $\begin{array}{c}(\mathrm{N}=16) \\
94 \\
6 \\
25\end{array}$ \\
\hline $\begin{array}{l}\text { Teacher Who Has Sex With } \\
\text { Student Should Be Punished } \\
\text { Minimally } \\
\text { Moderately } \\
\text { Severely }\end{array}$ & $\begin{array}{c}\text { Teacher/ } \\
\text { Head Teacher } \\
\text { Teacher/ } \\
\text { Head Teacher } \\
\text { Teacher/ } \\
\text { Head Teacher }\end{array}$ & $\begin{array}{c}(\mathrm{N}=60) \\
27 \\
20 \\
53\end{array}$ & $\begin{array}{c}(\mathrm{N}=21) \\
24 \\
19\end{array}$ & $\begin{array}{c}(\mathrm{N}=30) \\
17 \\
30\end{array}$ & $\begin{array}{c}(\mathrm{N}=16) \\
6 \\
38\end{array}$ \\
\hline
\end{tabular}

varying between 0 and 4 for each sex at different schools; hence school-based estimates are prone to considerable error.

In Kenya, while teachers in primary schools are not required to obtain a university degree, all teachers must have formal training. The most common certification level is designated $\mathrm{P} 1$, which can be obtained if one has achieved a grade of $\mathrm{C}$ or better on the Kenya Certificate of Secondary Education examination and attended teacher training college for two years or through merit promotion from a lower level. Levels below P1, that is, P2, P3, and P4, which are given to those who enter the system without completing secondary school, are increasingly being phased out. Levels above P1 can be obtained either through attendance at university or through merit promotions if one has been at a grade for at least five years. The majority of teachers in the schools we visited have certification at the P1 level. While the certification levels of male teachers do not vary much in high- and low-performing schoolsalthough somewhat surprisingly a greater proportion of those in high- 
performing schools are below P1 - there is more variation for female teachers, and it is in the expected direction. Female teachers in high-performing schools have higher levels of certification than their counterparts at lowperforming schools, or than their male colleagues at high-performing schools.

Teacher attitudes. We first explored preferences toward the teaching of boys and girls (see Table 8). To the extent that teachers have a preference, they favor boys. What is most striking is that women teachers at lowperforming schools are more favorably disposed to boys than their male counterparts at all schools and their female counterparts at high-performing schools. Over 40 percent of women faculty at low-performing schools prefer teaching boys. In high-performing schools 81 percent of women teachers have no preference, with the remaining 19 percent being partial to boys. This is roughly the same as the attitudes of male teachers in low-performing schools and not very different from the attitudes of male teachers at highperforming schools with the exception that, among the latter, a few more prefer teaching girls.

To determine what teachers think about the importance of education for girls and boys and their capacity for learning, we asked them such questions as what level of education girls and boys should reach, what subjects will provide the knowledge and skills to prepare boys and girls for adult life, and what subjects boys and girls find easier. Given the low percentage of Kenyans who are able to attend university, the answers to questions about the desirable level of education are a clear case of wishful thinking. Ninety-six percent of teachers think girls should go to university and 97 percent think boys should go (results not shown). There was more variation in the responses to questions on which subjects are important. Regarding both Math and English, teachers' 
views about importance differed for boys and girls. In high-performing schools, the majority of teachers of both sexes (between 73 and 81 percent) thought English and Math were important for both boys and girls, with a slight tendency to think Math more important for boys ( 73 vs. 67 percent for male teachers and 81 vs. 75 percent for female teachers). In low-performing schools, while male teachers were still apt to think Math important for both sexes, they were somewhat less inclined to think the same for English. Again, it is the female teachers in low-performing schools with aberrant attitudes. In low-performing schools they are less likely to indicate that Math and English, but especially Math, are important. In keeping with conventional stereotypes, few teachers think English is easier for boys, and not one thinks Math is easier for girls. Once again female teachers exhibit more variability. Those in highperforming schools are more likely to think English easier for girls and Math easier for boys than their counterparts in low-performing schools.

Finally we explored attitudes toward schoolgirl pregnancy and toward teachers engaging in sex with students. We asked teachers whether girls who become pregnant should be allowed to stay in school until just before they deliver. The vast majority indicated that girls should be forced to leave, with teachers in high-performing schools, particularly women, very much in favor of their being expelled. On the other hand, only a small percentage of teachers-more male than female-thought a boy should be made to leave if he were found to have impregnated a girl, a distinct case of a double standard operating. Not only do teachers think pregnant schoolgirls should be expelled, most think they should not be allowed to resume their education at the same school after delivery. We also asked teachers how they would deal with a colleague who was discovered to have had sex with a student. We categorized the responses into minimal action (where teachers responded "nothing," 
“interdiction," 21 or "counseling"), moderate action (where teachers responded "transfer," "suspension," or "pay for child"), and severe action (where teachers responded "dismissal" or "take to court"). More teachers in lowperforming schools think that a teacher who has sex with a student should not be punished.

Disaggregating teacher responses by sex is not particularly illuminating, at least as far as explaining why girls perform better in schools with more female teachers. Female teachers are not more enlightened than their male counterparts and, in low-performing schools, have a clear preference for teaching boys. While female teachers are thought to serve as role models for girls and their very presence might improve female participation in school (Hyde 1997), there is no evidence from other studies that female teachers are more sympathetic to or encouraging of their female pupils (Stromquist 1989; Anderson-Levitt, Bloch and Soumare, forthcoming); we find no evidence for this either.

Harassment. Focus groups held with adolescents aged 12-14 and 15-19 in the same districts about six months prior to the school survey suggested that considerable sexual harassment takes place at school. ${ }^{22}$ Participants discussed sexual relationships between male and female students, between male teachers and female students, and between female teachers and male students. The following quotes illustrate the experiences of the adolescents:

"Boys come and hold our breasts in class even when the teacher is there; he pretends that he is packing something." (Girl, 15-19, Kilifi)

"This abusive behavior from boys happens everywhere, in the streets, in school, and in discos, and it is normally boys we know 
in school and at home.” (Girl, 15-19, Nakuru)

"Some touch their breasts even in classrooms." (Boy, 15-19, Nakuru)

"They fondle the girls' breast in the classroom, kiss them and tickle them by poking them in the ribs." (Boy, 15-19, Kilifi)

"A girl was followed by a teacher. The teacher convinced her that he marks the KCPE composition so he would give her 30 or 33 out of 40. She gave in because of that and they had sex." (Girl, 15-19, Kilifi)

"Mostly relationships between teachers and girls are found in primary school due to immaturity on the part of the girls who fall for the teachers just because they are smartly dressed." (Boy, 1519, Kilifi)

"In situations where female teachers have affairs with boys, the teachers give the boys money and also favor them in exams; some female teachers have affairs with boys who come from rich families." (Boy, 15-19, Kilifi)

"Maybe if the girl doesn't want sex, the headmaster might force and rape her"; "When the girl goes to visit the teacher, the teacher will force her." (Two girls, 12-14, Nakuru)

That boys and girls from several districts described the same behaviors (for example, touching of breasts in class) indicates that these are familiar occurrences. These findings led us to explore the issue of harassment in greater depth. We asked students whether they had experienced harassment and had our field teams record whether harassment was detected outside classrooms, in hallways or in the school yard. While we expected that some boys would report they were harassed at school, we were surprised that nearly the same proportion of boys and girls reported that they were pressured to have sex (see Table 9). Interestingly, our observers noticed no sexual harassment of boys at any school but saw instances of sexual harassment of 
girls at 14 percent of low-performing and 17 percent of high-performing schools. Occasionally school staff discussed this issue with the field team supervisors:

"One noticeable thing was that girls and boys don't talk or even walk together when going home. The home science teacher mentioned that this was because boys are dangerous and the girls have been cautioned now and then such that they fear the boys. According to the teacher, boys are dangerous because they can make girls pregnant." (Low parental education, low-performing school)

While harassment of boys of a nonsexual nature was observed in a few schools, harassment of girls was seen in 62 percent of low-performing and 42 percent of high-performing schools. When we asked boys and girls about harassment in the student interviews, specifically whether they were teased, hit, tripped, or blocked by a member of the opposite sex, again there was more reporting of harassment of girls. We created an index ranging from 0 to 4 measuring the prevalence and intensity of two types of harassment, verbal and physical. $^{23}$ We also asked both boys and girls whether there was harassment of girls at the toilets, specifically whether boys tease girls or try to watch girls or block them from using the toilet. Both boys and girls indicated there was less harassment of the opposite sex than that sex reported of itself. For example, the index of girls' reporting of girls' harassment in high-performing schools is 1.33, whereas the index for boys' reporting of girls' harassment is .62 .

Table 9 School and classroom dynamics - harassment

\begin{tabular}{l|c|c|c}
\hline & & $\begin{array}{c}\text { Low- } \\
\text { Performing } \\
\text { Schools (N=21) }\end{array}$ & $\begin{array}{c}\text { High- } \\
\text { Performing } \\
\text { Schools } \\
(\mathbf{N}=12)\end{array}$ \\
\hline $\begin{array}{l}\text { Hescription of Variable } \\
\text { Pressured to have sex }\end{array}$ & Instrument & Percentage & Percentage
\end{tabular}




\begin{tabular}{|c|c|c|c|}
\hline $\begin{array}{c}\text { Boys } \\
\text { Girls } \\
\text { Sexual harassment } \\
\text { Boys } \\
\text { Girls } \\
\text { Nonsexual harassment } \\
\text { Boys } \\
\text { Girls }\end{array}$ & $\begin{array}{l}\text { Student } \\
\text { Student } \\
\text { Inventory } \\
\text { Inventory } \\
\text { Inventory } \\
\text { Inventory } \\
\end{array}$ & $\begin{array}{c}18 \\
12 \\
\\
\text { 0 } \\
14 \\
5 \\
62 \\
\end{array}$ & $\begin{array}{c}16 \\
17 \\
\\
\mathbf{0} \\
17 \\
\\
8 \\
42 \\
\end{array}$ \\
\hline $\begin{array}{c}\text { Reporting of boys' harassment } \\
\text { By boys } \\
\text { By girls } \\
\text { Reporting of girls' harassment } \\
\text { By boys } \\
\text { By girls }\end{array}$ & $\begin{array}{l}\text { Student } \\
\text { Student } \\
\text { Student } \\
\text { Student }\end{array}$ & 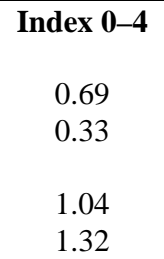 & $\begin{array}{c}\text { Index } \mathbf{0 - 4} \\
\begin{array}{c}0.33 \\
0.35 \\
\\
0.62 \\
1.33\end{array}\end{array}$ \\
\hline $\begin{array}{l}\text { Reporting of girls' harassment at toilets } \\
\text { By boys } \\
\text { By girls } \\
\text { Pregnancy checks } \\
\text { Reported by head teacher } \\
\text { Reported by girls this term }\end{array}$ & $\begin{array}{l}\text { Student } \\
\text { Student } \\
\text { Head Teacher } \\
\text { Student }\end{array}$ & $\begin{array}{c}\text { Percentage } \\
8 \\
12 \\
14 \\
3 \\
\end{array}$ & $\begin{array}{c}\text { Percentage } \\
2 \\
14 \\
8 \\
2\end{array}$ \\
\hline
\end{tabular}

Finally, we examined whether schools required girls to undergo pregnancy tests, a practice reported in other African countries (Hyde 1997) that we label "administrative harassment," because such tests can be seen as an unwarranted intrusion into girls' lives. We asked the head teachers whether girls at their schools are checked for pregnancy, and we asked the girls whether they were checked for pregnancy after they returned from the last Easter holiday. On average, only a small percentage of students reported they had been checked last term, although the practice is not rare, at least as reported by head teachers at low-performing schools. Our field team supervisors discussed the issue of pregnancy tests with head teachers:

"One head teacher told me that girls who are suspected to be pregnant are referred to the clinic for [a] pregnancy test. I [the supervisor] questioned what their criteria for suspicion was. He said that if a girl was once active in sports and suddenly became inactive then she was a suspect. Also [he] mentioned that if they have a mild infection like fever which went on for a few days, she 
was to be checked. The other reason was that if a girl's performance drops suddenly, then she had something on her mind which certainly according to the head teacher was pregnancy; the last reason was change in physical appearance." (Low parental education, low-performing school)

"The head teacher believes that pregnancy is not a major problem; but what usually happens is that when somebody is suspected, she is called by the head teacher and asked whether she is pregnant. If she denies she is closely monitored for any changes in body. Most people who are suspected are normally girls who grow fat within a short period of time." (High parental education, high-performing school)

While classroom observation did not uncover any teacher behavior that is systematically different toward boys and girls or between high- and lowperforming schools, interviews with head teachers, teachers, and students; observers' reports from outside the classrooms; and focus group discussions in the same districts in which the school data were collected indicate that some schools-perhaps even many-do not provide a particularly friendly environment for adolescent girls. To the extent that teachers would rather teach one sex than the other, they prefer boys. Teachers are eager to expel pregnant girls, but are tolerant of boys who impregnate girls. Harassment, both sexual and, more often, nonsexual, is common. Yet this unfriendly environment appears to be unrelated to students' performance, at least as measured by the KCPE exam. While there are girls who manage to do well on exams despite the hostile atmosphere, the question is whether these schools undermine girls in other ways. As we argued earlier, the development of cognitive competency is but one element marking a successful transition to adulthood. The fulfillment of educational goals, the avoidance of pregnancy, and the development of self-esteem are others. 
Family life education. The final input we explored was the availability of and attitudes toward family life education (FLE) in schools as well as the reproductive health knowledge of students (see Table 10). While FLE is not an examinable subject and therefore may be taken less seriously by students and teachers alike, not providing information on reproductive health potentially exposes adolescents to considerable risk in societies such as Kenya, where rates of sexual activity among young people are high (Bledsoe and Cohen 1993). Given that girls are at risk of pregnancy and that the incidence of HIV is higher for adolescent girls than boys in East Africa because of the large age differences between sexual partners, girls are particularly disadvantaged by a lack of reproductive health information (Nunn et al. 1994; Barongo et al. 1992). While all of the head teachers claim that "adolescent growth and development" ${ }^{24}$ is taught in school and most teach something about physical changes during puberty, the value of the information transmitted is questionable. No school, either low- or highperforming, provides information on family planning and only a few (one lowperforming, two high-performing) teach anything about sexually transmitted diseases. 
Table 10 Family life education

\begin{tabular}{|c|c|c|c|}
\hline Description of Variable & Instrument & $\begin{array}{c}\text { Low- } \\
\text { Performing } \\
\text { Schools }(\mathrm{N}=\mathbf{2 1})\end{array}$ & $\begin{array}{c}\text { High- } \\
\text { Performing } \\
\text { Schools }(\mathrm{N}=12)\end{array}$ \\
\hline $\begin{array}{l}\text { Curriculum } \\
\text { Courses taught: } \\
\text { Adolescent growth and development: } \\
\text { Development change, puberty } \\
\text { Biology, reproduction } \\
\text { Boy/girl relations } \\
\text { Consequences of irresponsible } \\
\text { behavior } \\
\text { Family planning } \\
\text { STDs }\end{array}$ & $\begin{array}{l}\text { Inventory } \\
\text { Inventory } \\
\text { Inventory } \\
\text { Inventory } \\
\text { Inventory } \\
\text { Inventory } \\
\text { Inventory }\end{array}$ & $\begin{array}{c}\% \\
100 \\
81 \\
33 \\
33 \\
19 \\
0 \\
5\end{array}$ & $\begin{array}{c}\% \\
100 \\
83 \\
50 \\
42 \\
8 \\
0 \\
17\end{array}$ \\
\hline $\begin{array}{l}\text { Teacher Attitudes } \\
\text { Approves teaching of: } \\
\text { Adolescent growth and development } \\
\text { Puberty, menstruation } \\
\text { Reproductive physiology } \\
\text { AIDS/STDs } \\
\text { Sexuality } \\
\text { Family planning }\end{array}$ & $\begin{array}{l}\text { Teacher/Head Teacher } \\
\text { Teacher/Head Teacher } \\
\text { Teacher/Head Teacher } \\
\text { Teacher/Head Teacher } \\
\text { Teacher/Head Teacher } \\
\text { Teacher/Head Teacher }\end{array}$ & $\begin{array}{l}\% \\
90 \\
88 \\
86 \\
88 \\
58 \\
49 \\
\end{array}$ & $\begin{array}{l}\% \\
90 \\
90 \\
83 \\
90 \\
44 \\
35 \\
\end{array}$ \\
\hline $\begin{array}{l}\text { Student Knowledge } \\
\text { Correct responses on: } \\
\text { Pregnancy risk questions } \\
\text { Total } \\
\text { Boys } \\
\text { Girls } \\
\text { AIDS/STD questions } \\
\text { Total } \\
\text { Boys } \\
\text { Girls }\end{array}$ & $\begin{array}{l}\text { Student } \\
\text { Student } \\
\text { Student } \\
\text { Student } \\
\text { Student } \\
\text { Student }\end{array}$ & $\begin{array}{l}34 \\
37 \\
30 \\
\\
57 \\
60 \\
54 \\
\end{array}$ & $\begin{array}{l}\% \\
\\
39 \\
37 \\
40 \\
\\
63 \\
65 \\
59 \\
\end{array}$ \\
\hline & & $\begin{array}{c}\text { Not Taught } \\
(\mathbf{N}=\mathbf{2 0})\end{array}$ & $\begin{array}{l}\text { Taught } \\
(\mathrm{N}=13)\end{array}$ \\
\hline $\begin{array}{l}\text { Student Knowledge by Whether } \\
\text { Curriculum Covers Biology/ } \\
\text { Reproduction } \\
\text { Correct responses on: } \\
\text { Pregnancy risk questions } \\
\text { Boys } \\
\text { Girls } \\
\text { Student Knowledge by Whether } \\
\text { Curriculum Covers STDs } \\
\text { Correct responses on: } \\
\text { AIDS/STD questions } \\
\text { Boys } \\
\text { Girls }\end{array}$ & $\begin{array}{l}\text { Student } \\
\text { Student } \\
\text { Student } \\
\text { Student }\end{array}$ & $\begin{array}{c}38 \\
32 \\
(\mathbf{N}=\mathbf{3 0}) \\
\\
\\
62 \\
55\end{array}$ & $\begin{array}{c}\% \\
\\
36 \\
36 \\
(\mathbf{N}=3) \\
\\
62 \\
60\end{array}$ \\
\hline
\end{tabular}


An examination of texts used in secondary school for the Social Education and Ethics course, a subject that is examined and is supposed to convey useful information on the problems encountered by adolescents, provides further confirmation that little of use on this topic is being conveyed in primary schools. The texts discuss physical changes at puberty but do not discuss sexuality, pregnancy, STDs, or contraception. Students are simply admonished to refrain from sex before marriage either because it can be dangerous or because, while pleasurable, it is morally reprehensible:

...even in the African traditional set up friendships between boys and girls were encouraged. ...But what kind of friends do we need, and what for? ... We should .... try to make friendships with people who are unlikely to influence us into acts that may bring us problems. ... Quite often young men tend to relate to young girls mainly for sexual ambitions and benefits. Common results of such type of relationships are often disease and pregnancy which may easily have negative effects on our health and education. Therefore, despite the growing sexual urge that is common in this stage of development, refrain from sexual indulgences need [sic] to be understood as the best way to avoid the social and health problems of sex (Masolo and Ongonga 1988: 36).

Another text uses a food analogy to make the point that sex is for procreation and thus should not be engaged in before marriage:

We must eat the appropriate amounts and at appropriate times. It is not good, for example, for a four-month-old baby to eat Kentucky Fried Chicken with ugali or to eat 'chapati na kima.' In order to be pleasurable and nourishing, good food needs to be eaten only by people of a proper age in correspondingly appropriate amounts... In ethical terms, this example shows us a very important principle: that the goodness of any act depends on the amount of objective good that it can produce at an given time. ... Now, where does sex before marriage lie? Generally, sex is a 
pleasurable act. But like food, its value is not just pleasure. It also has a purpose or major value.... The purpose of sex is to raise children. ...is sex permissible just between any adults? No. Why not? Because ... its main purpose is to raise children. (Masolo 1988: 43-44; emphasis in original)

In addition to determining what topics were included in the adolescent growth and development curriculum, we asked teachers whether they approved of particular subjects being taught. Most thought that discussions of puberty, menstruation, and reproductive physiology should be included in the primary school curriculum. Despite the fact that information on STDs is currently not being taught in the vast majority of schools, most teachers would like this topic to be covered. There is much more disagreement about sexuality and family planning. Fewer teachers are in favor of these subjects being taught, with those who work in low-performing schools being more likely to approve of them, perhaps because they detect a greater need. The following comments illustrate the range of attitudes toward family life education.

"The head teacher is only for family life education if it is taught by a committed Christian who is also a teacher, whether they are experimenting or not. ... She is strongly against sex education." (High parental education, low-performing school)

"The curriculum master is of the opinion that sex is a very big problem here that should be checked. Gave an example of two girls who have children, one gave birth only three months ago and is still breastfeeding. She is a Standard 7 girl, aged 14. He says they should be taught everything in family life education as this would help reduce the rate of pregnancy." (Low parental education, low-performing school)

"This is the first school we went to after the President had banned the FLE in schools and we really had to answer many questions. The teachers were now wondering whether we would really be 
able to help the students as they grow up as they [FLE] had now been banned." (Low parental education, low-performing school; see endnote 24)

"The head teacher is against family planning being taught in school, saying that this might make the students experiment. He at the same time says that they are even experimenting without necessarily being taught about family planning." (High parental education, high-performing school)

In the student instrument, 15 knowledge questions were asked about transmission and prevention of STDs including AIDS, and three about pregnancy risk including when during the month a woman is most likely to become pregnant. From these questions two scores were computed, one measuring knowledge of AIDS and STDs and the other knowledge about pregnancy risk. While students are moderately well informed about AIDS and STDs, many are ignorant about when and under what circumstances pregnancy is likely to occur. In our sample, the score for AIDS and STDs is 57 percent correct in the low-performing schools and 63 percent correct in the high-performing. The corresponding scores for pregnancy are 34 percent and 39 percent (panel 3, Table 10). Girls are slightly less knowledgeable than boys. Surprisingly, compared to students in schools where the subject is not taught, reproductive health knowledge of students in schools that ostensibly include the material we tested is not much greater, and for boys is about the same (see bottom panel of Table 10).

Finally, while there is a positive relationship between cognitive ability, at least as measured by the $\mathrm{KCPE}$, and reproductive health knowledge for girls, it is quite weak; for boys, it is non-existent (panel 3, Table 10). This finding suggests that, basing the measurement of school effectiveness solely on performance on academic exams neglects a critical dimension of adult 
functioning, a dimension that can have consequences for health as well as for school retention.

To the extent that FLE is included in the primary school curriculum, little of use is apparently being conveyed, at least in our sample of schools. Although information on STDs is available in only three schools, the vast majority of teachers approve of its being taught. While family planning and sexuality, which are not covered in any school, meet with more disapproval, a considerable fraction of teachers would like these subjects to be taught, particularly in low-performing schools, where girls, in particular, are less knowledgeable.

\section{CONClusions}

Our data on Kenyan schools depict a harsh environment for adolescent boys and girls in the final years of primary school, when they are preparing for a critical exam that will determine whether or not they will be able to continue to secondary school. In schools that range the spectrum in terms of performance and parental status, disorganization coexists with strict punishment, minimal comforts are lacking, learning materials are scarce, learning occurs by rote, and sex is practiced but not taught. Girls score lower than boys in the national KCPE exams, especially in low-performing schools. Teachers' attitudes and behavior reveal lower expectations for adolescent girls, traditional assumptions about gender roles, and a double standard about sex.

Our focus in this paper has been on gender differences. We have not attempted to identify all the factors that make a school high- or lowperforming but instead sought to determine the ways in which low- and high-

performing schools may differ in their treatment of girls. We have found that 
girls suffer from negative attitudes and discriminatory behavior in both sorts of schools. High-performing schools have more female teachers, who presumably serve as role models for girls, and these teachers are more evenhanded in their preferences than their female counterparts in low-performing schools, who strongly prefer teaching boys. Other evidence suggests, however, that even girls in high-performing schools are less likely than boys to experience good interactions with teachers or to receive other types of encouragement such as school prizes. Thus it appears that "better" schools, measured solely according to exam performance, are not necessarily more gender equitable even if they are better able to prepare students for the $\mathrm{KCPE}$ exam. Indeed, teachers in high-performing schools are even less supportive of teaching sexuality or family planning than teachers in low-performing schools, probably a reflection of fears among teachers in schools that do relatively well that family life education could introduce a disruptive element into the school environment.

Girls have much to gain from doing well in school even if they are treated poorly. Those who have a chance to go to secondary school will reap significant returns from better job and marriage opportunities. Unfortunately for most students in Kenya, a primary certificate is a terminal degree. The goal of primary school is to provide students with practical skills. To the extent that primary schools limit students' access to information about the practical realities of sex and family planning, it does them a disservice. This is particularly so for girls, who are more likely to suffer by not having accurate information. Furthermore, by demeaning girls' intelligence, and not providing them with special encouragement to counteract the sexual stereotypes they encounter outside of school, primary school teachers limit girls' incentives to continue their education and to delay marriage and childbearing. 


\section{Appendix}

Key elements of each of the five school-based instruments are summarized below.

The classroom observation instrument includes data on: (1) the day's lesson; (2) the seating arrangement; (3) the allocation of class time; (4) individual student-teacher interactions; (5) an inventory of classroom instructional materials; (6) teacher actions; (7) treatment of girls and boys; and (8) disciplinary actions for late arrival and noncompliance with uniform regulations. The primary goal of this instrument is to determine whether teachers are more responsive to and encouraging of boys and correspondingly more dismissive or contemptuous of girls. The instrument is similar in content to the Sadkers' (Sadker and Sadker 1995; Sadker et al. n.d.) observation form, which is used to assess the treatment of girls in US schools. The observer is asked to count and compare the number of times the teacher calls on boys and girls both in student-initiated and teacherinitiated interactions and to make a judgment about the nature of the teacher's response: complimentary, derogatory, encouraging, expansive, etc. In addition, the observer is asked to compute classroom time allocation, specifically how time is divided between lecture, group work, copying from blackboards, doing exercises, class discussion, group recitation, and discipline. The observer also collects data on the degree to which boys' and girls' interactions with peers of the opposite sex involve teasing or physical abuse.

The interview with the head teacher (that is, principal/headmaster) includes data on: (1) term length, school hours, and shifts; (2) school policies; (3) students; (4) teachers; (5) attitudes about family life education; (6) extracurricular activities; (7) school financing; (8) attitudes about the education of boys and girls; (9) attitudes about sex and schoolgirl pregnancy; and (10) personal background. In addition to collecting this basic information, the instrument is intended to assess 
whether or not the head of the school has positive attitudes toward the education of girls. Questions are asked on subjects girls and boys should take, on whether particular subjects are easier for boys or girls to learn, and on the level of education boys and girls should attain. In addition there are questions on whether the head approves of family life education being taught in schools and, if so, the topics that should be taught as part of such a curriculum. Finally, there is a section asking the head about his/her attitude toward girls who become pregnant while still in school and on whether pregnant girls should be permitted to stay in school until delivery and to return after childbirth.

The interview with the classroom teacher includes data on: (1) work responsibilities and benefits; (2) supervision; (3) attitudes about the education of boys and girls, sex and schoolgirl pregnancy, and family life education; (4) job satisfaction; (5) participation in tutoring; and (6) personal background. The teacher instrument is similar to the head teacher questionnaire, with the exception that questions on the school as a whole are not included and there are additional questions on whether the teacher has been supervised either internally or by someone from the Ministry of Education. There are also questions on satisfaction with various aspects of the job-including salary, hours taught, in-service training, the quality of the students and the facilities - and outside tutoring services provided by teachers.

The school inventory and observation instrument includes data on: (1) classroom and instructional space, sports equipment, and sports played; (2) condition of classroom buildings; (3) school office, electricity, water, and vehicles; (4) attendance register; (5) family life education; (6) supplementary staff; (7) meals; (8) harassment of girls in hallways; and (9) toilet facilities. This instrument has three goals: to collect detailed data on the quality of the physical plant, including toilets and laboratory and physical education equipment; to collect 
detailed data by grade on the topics covered in the social education and ethics or home science courses; and to observe whether there is any harassment-sexual or otherwise — of girls outside of classrooms and near toilets.

The student questionnaire, which is the same for boys and girls except for a few items, includes data on: (1) personal and family background; (2) familial payment of school fees; (3) student status; (4) possession of textbooks; (5) recent experience with teacher absenteeism and school closings; (6) experience with duties and punishments; (7) school policies; (8) homework and tutoring; (9) support staff and health services; (10) extracurricular activities; (11) attitudes about the education of boys and girls; (12) treatment of boys and girls in school; (13) satisfaction with the school; and (14) knowledge of reproduction and reproductive health. A major objective of the student questionnaire is to permit a validity check on the data generated by the two sets of observation and teacher forms. A potential weakness of school and classroom observation is that teachers are on their best behavior when the field team visits. Furthermore, when teachers are asked questions, they frequently provide socially desirable responses rather than responses that reflect reality. For example, are there unexpected school closings and teacher absences that teachers did not report? Are students required to perform domestic or other tasks for teachers that the observer did not see? Are girls checked for pregnancy at the beginning of the school term? Do teachers discourage students? If so, how? Do teachers scold or punish students? Do male teachers sexually harass their female pupils? By asking the students these questions in confidence, we expect to get more accurate answers. 


\section{Notes}

1. We thank Kathryn Anderson-Levitt, Anthropology Department, University of Michigan, for sharing her annotated bibliography on girls and schooling in Africa.

2 We recognize that, in certain school settings, the school itself may be a venue for girls' exposure to sexual harassment and thus an additional risk factor for girls.

3 For a session on children's schooling in developing countries for the 1997 Annual Meeting of the Population Association of America, most of the papers submitted focused on the familial determinants of enrollment and achievement.

4. Positive attributes for girls mainly had to do with their appearance.

5. Although Appleton (1995) states that the numerical scores are standardized such that the mean for each paper is 50 and the mean total score is 350 with a standard deviation of 15 , we have been told by Kenyans who have worked for the National Examinations Council that it is the letter score distribution that is standardized and therefore does not vary from year to year. What does fluctuate is the distribution of numerical scores. Moreover, Makau (1994), who was formerly head of the Examinations Council, reported results for the $1993 \mathrm{KCPE}$ in a conference paper. He indicated that there was a constant letter score distribution across exam papers, with about one-quarter of students scoring between $\mathrm{A}$ and $\mathrm{B}-$, somewhat over half scoring between $\mathrm{C}+$ and $\mathrm{D}+$, and somewhat under a quarter scoring between $\mathrm{D}$ and $\mathrm{E}$. 
6. Three of the primary schools in Nakuru are single sex (two all girls and one all boys); therefore data from these schools cannot be included when gender differences are being examined.

7. It is worth noting that the two all-girls' schools fall into the highperforming category; indeed among our 36 schools, one is the highest scoring, the other, the ninth highest.

8. To determine whether a school should be categorized as high or low on exam scores, we proceeded as follows: We averaged together the percentage of girls scoring B- and above in six out of seven of the required papers, thus arriving at an average rate. To facilitate data collection, we designated a particular score rather than asking for a numerical average since schools do not readily produce tables of exam results by sex. The field teams could easily scan the exam results for each school and produce a count above B-, which obviated the need for any detailed computation. We did not include the Kiswahili exam in our average because performance on this paper did not correlate highly with performance on the other six (correlation coefficients between .19 and .33).

9. If the student knew the education level of only one parent, we used that information and weighed it so the parent counts twice. Students who did not know the education level of either parent were considered missing. In 24 of the 33 schools, some students did not know the education level of either parent. In only five of those schools, however, did the number of students without knowledge of parental education reach 10 percent 
and in no case did it exceed 20 percent.

10. The score used to compare our sample to Kenya as a whole is not the score used to divide the sample into two groups. (See endnote 8.) Here Kiswahili was added. Moreover, boys' scores were also included.

11. The supervisors made numerous comments about the poor quality of the student data maintained by the school. Stated the supervisor upon arrival at a Kilifi primary school: "It was noticed that just like in the previous two schools, records on age and enrollment/promotion were not ... accurate." Thus data on students' ages discussed here come from the self-administered student questionnaire. Since students were randomly selected for the interview and in small schools constitute the entire student body in the standards under consideration, the age data derived from the student sample should be representative of all students who attend school unless absence is selective according to age.

12. The reality is that, while re-sitting the exam may be beneficial, grade repetition apparently is not (Appleton 1995).

13. In one Nakuru school the supervisor commented: "Most classes were empty or with very few students. This she [the home science teacher] said was because pupils had been sent home for school fees; most parents don't bother to pay fees on time during weeding season from mid-April to mid-May because they need an extra hand at home. This she said was true for both girls and boys."

14. The supervisor said about one school in Nakuru: "Repeaters are so many in this school. This is because [of the] importance ... attached to 
good performance so that only the best students are promoted."

15. For the 28 primary schools that have one shift, the average school day is over eight hours; for the eight double-shift schools, the school day is about four hours. Some of the time in which school is open is devoted to "prep," where students are left alone to do school work. Typically, our field teams arrived at the schools between 7 and 7:30 in the morning to find the students busy with prep. Classes begin around 8am and end around $4 \mathrm{pm}$, though students often stay later. Said one supervisor about a primary school in Nakuru: "The students work very hard getting to school by $7 \mathrm{am}$ and leaving at $6 \mathrm{pm}$; they really complain that they don't have their own free time."

16 According to our household-based data, approximately one-third of adolescent girls who attend primary school and have their menstrual period use rags; the vast majority of the others use pads or cotton wool. While rags need to be washed out, girls would not do so at schools.

17. Interestingly, in an article about Tegla Loroupe, the Kenyan winner of two New York City Marathons, the New York Times stated that "In the East African nation, many girls compete in sports through high school, but their careers often reach a premature finish line marked by the societal expectations of marriage and domestic subservience" (Longman 1996).

18. The adolescent household interview that is part of this study, but has yet to be analyzed, collected time and mobility data .

19. In two low-performing schools there was a problem with the data on the 
sex distribution of teachers; thus we have data on 19 of 21 schools.

20. Teachers are assigned to schools centrally through the Teacher Service Commission. Because transfers are permitted, it appears that there is more staff turnover in less desirable regions or schools.

21. It is our understanding that "interdiction" is simply a "slap on the hand."

22. These focus groups were held with adolescent boys and girls aged 12-19 in November 1995 to help us develop the structured questionnaires for our school and community surveys.

23. $0=$ no harassment, $1=$ either verbal or physical harassment occasionally, $2=$ both verbal and physical harassment occasionally or one of them often, $3=$ one type often and the other occasional, and 4=both types often.

24. Because of the sensitivity surrounding family life education in Kenyan schools-periodically the President makes public statements denouncing it and there has been a widely publicized public burning of FLE texts in Nairobi-we were instructed by our Ministry of Education colleagues to use the expression "Adolescent Growth and Development." In the top panel of Table 10, where we refer to courses taught, the subjects listed are those named by head teachers or other teachers as part of the adolescent growth and development curriculum at the school. Since there is no standard curriculum, we grouped similar topics together to analyze the data. Thus if we were told that "development" or "change" or "puberty" was taught, we put them into one category. 


\section{References}

Abraha, Seged et al. 1991. "What factors shape girls' school performance? Evidence from Ethiopia," International Journal of Educational Development 11, no. 2: 107-118.

Ainsworth, Martha, Kathleen Beegle, and Andrew Nyamete. 1996. "The impact of women's schooling on fertility and contraceptive use: A study of fourteen sub-Saharan African communities," World Bank Economic Review 10, no. 1: 85-122.

Anderson-Levitt, Kathryn M., Marianne Bloch, and Aminata M. Soumare. "Inside classrooms in Guinea: girls' experiences," in Marianne Bloch, Josephine Beoku-Betts, and Robert Tabachnick, Women and Education in Sub-Saharan Africa. Boulder, CO: Lynne Reinner Publishers, forthcoming.

Appleton, Simon. 1991. "Education," in Simon Appleton et al. (eds.), Public Services and Household Allocation in Africa: Does Gender Matter? Washington, DC: Women in Development Division, World Bank.

—. 1995a. "Gender inequalities in human capital accumulation: Evidence from two African countries," Centre for the Study of African Economies Working Paper. Oxford: Oxford University.

_. 1995b. "Exam determinants in Kenyan primary school: Determinants and gender differences," McNamara Fellowships Program, Economic Development Institute of the World Bank. Washington, DC: The World Bank.

Bali, Shashi K., Pieter J. D. Drenth, Henk van der Flier, and Willie C. E. Young. 1984. Contribution of Aptitude Tests to the Prediction of School Performance in Kenya: A Longitudinal Study. Albasserdam: Swets and Zeitlinger.

Barongo, Longin R. et al. 1992. "The epidemiology of HIV-1 infection in urban areas, roadside settlements and rural villages in Mwanza Region, Tanzania," AIDS 6 no. 12: 1521-1528. 
Biraimah, Karen Coffyn. 1980. "The impact of western schools on girls' expectations: A Togolese case," Comparative Education Review 24: S197-S209.

—. 1989. "The process and outcomes of gender bias in elementary schools: A Nigerian case," Journal of Negro Education 58, no.1: 5067.

Bledsoe, Caroline H. 1990. "School fees and the marriage process for Mende girls in Sierra Leone," in Peggy Reeves Sanday and Ruth Gallagher Goodenough (eds.), New Directions in the Anthropology of Gender, pp. 283-309. Philadelphia: University of Pennsylvania.

- 1992. "The cultural transformation of western education in Sierra Leone," Africa 62, no. 2: 182-202.

Bledsoe, Caroline H. and Barney Cohen. 1993. Social Dynamics of Adolescent Fertility in Sub-Saharan Africa. Washington, DC: National Academy Press.

Bloch, Maurice. 1993. "The uses of schooling and literacy in a Zafimaniry village," in Brian Street (ed.), Cross-Cultural Approaches to Literacy, pp. 87-109. Cambridge, UK: Cambridge University Press.

Boothroyd, Roger A. and David W. Chapman. 1987. "Gender differences and achievement in Liberian primary school children," International Journal of Education Development 7, no. 2: 99-105.

Card, David and Alan B. Krueger. 1996. "School resources and student outcomes: An overview of the literature and new evidence from North and South Carolina," Journal of Economic Perspectives 10, no. 4: 3150 .

Cleghorn, Ailie, Marilyn Merritt, and Jared O. Abagi. 1989. "Language policy and science instruction in Kenyan primary schools," Comparative Education Review 33, no. 1: 21-39.

Davidson, Jean and Martin Kanyuka. 1992. "Girls' participation in basic education in southern Malawi," Comparative Education Review 36, no. 4: 446-466. 
Davies, B. 1994. "Gender theories in education," in Torsten Husen and T. Neville Postlethwaite (eds.), The International Encyclopedia of Education, second edition, vol. 5, pp. 2453-2458. Tarrytown, NY: Elsevier Science/Pergamon.

Ferguson, Alan. 1988. Schoolgirl Pregnancy in Kenya: Report of a Study of Discontinuation Rates and Associated Factors. Nairobi: Kenya Ministry of Health, Division of Family Health.

Finn, Heremy D., Janet Reis, and Loretta Dulberg. 1982. "Sex differences in educational attainment: The process," in Gail P. Kelly and Carolyn M. Elliott (eds.), Women's Education in the Third World: Comparative Perspectives, pp. 107-125. Albany: State University of New York Press.

Fuller, Bruce and Prema Clarke. 1994. "Raising school effects while ignoring culture? Local conditions and the influence of classroom tools, rules, and pedagogy," Review of Educational Research 64, no. 1: 119-157.

Fuller, Bruce, Haiyan Hua, and Conrad W. Snyder. 1994. "When girls learn more than boys: The influence of time in school and pedagogy in Botswana," Comparative Education Review 38, no. 3: 347-376.

Fuller, Bruce and Conrad W. Snyder. 1991. "Vocal teachers, silent pupils? Life in Botswana classrooms," Comparative Education Review 35, no. 2: 274-294.

Fuller, Bruce. 1987. "What factors raise achievement in the third world?" Review of Educational Research 57: 255-292.

Glewwe, Paul. 1996. "School quality, student achievement and fertility in developing countries: An assessment of current knowledge and recommendations for future research," paper presented at the National Academy of Sciences Workshop on Education and Fertility in the Developing World, 29 February - 1 March, Washington, DC.

Glewwe, Paul and Hanan Jacoby. 1993. "Delayed primary school enrollment and childhood malnutrition in Ghana; An economic analysis," World Bank Living Standards Measurement Study, Working Paper No. 98. 
Washington, DC: The World Bank.

- 1994. "Student achievement and schooling choice in low income countries." The Journal of Human Resources 29, no. 3: 843-864.

Grisay, Aletta. 1984. "Analyse des inégalités de rendement liées au sexe de l'élève dans l'enseignement primaire Ivoirien," International Review of Education 30: 25-39.

Hanushek, Eric A. 1995. "Interpreting recent research on schooling in developing countries," The World Bank Research Observer 10, no. 2: 227-46.

Hanushek, Eric A. and Victor Lavy. 1994. "School quality, achievement bias, and dropout behavior in Egypt," World Bank Living Standards Measurement Study, Working Paper No.107. Washington, DC: The World Bank.

Harbison, Ralph W. and Eric A. Hanushek. 1992. Educational Performance of the Poor: Lessons from Rural Northeast Brazil. New York: Oxford University Press.

Herrera, Linda. 1992. "Scenes of schooling: Inside a girls' school in Cairo," Cairo Paper in Social Science, 15, Monograph 1. American University of Cairo Press.

Heyneman, Stephen P. and William A. Loxley. 1983. "The effect of primaryschool quality on academic achievement across twenty-nine high- and low-income countries," American Journal of Sociology 88, no. 6: 1162-1194.

Hill, M. Anne and King, Elizabeth M. 1993. "Women's education in developing countries: An overview" in Elizabeth M. King and M. Anne Hill (eds.), Women's Education in Developing Countries: Barriers, Benefits, and Policies. Baltimore: Johns Hopkins University Press.

Hyde, Karin A. L. 1993. "Sub-Saharan Africa," in Elizabeth M. King and M. Anne Hill (eds.), Women's Education in Developing Countries; Barriers, Benefits, and Policies. Baltimore: Johns Hopkins University 
Press.

1997. "Barriers to equality of educational opportunity within mixedsex secondary schools in Malawi," in Sheena Erskine and Maggie Wilson (eds.), Gender Issues in International Education: Beyond Policy and Practice. New York: Garland Press.

Hyde, Karin A. L. and Esme Kadzamira. 1994. "Girls' attainment in basic literacy and education project: Knowledge, attitudes and practices pilot survey," final report, Centre for Social Research, University of Malawi.

International Council for Health, Physical Education, Recreation, Sport and Dance. 1996. Theme: Women and Sports Past, Present and Future (The Brighton Declaration On Women and Sport). 1st ICHPER-SD Asia Conference on Women and Sports Held at the Holiday Inn Manila Pavilion, Manila Philippines 7-10 March.

Jejeebhoy, Shireen. 1995. Women's Education, Autonomy, and Reproductive Behavior: Experience from Developing Countries. Oxford: Clarendon Press.

Jimenez, E. and Marlene Lockheed. 1989. "Enhancing girls' learning through single-sex education," Educational Evaluation and Policy Analysis 11, no. 2: 117-142.

Kremer, Michael, Sylvie Moulin, David Myatt, and Robert Namunyu. 1996. "Textbooks, class size and test scores: Evidence from a prospective evaluation in Kenya," mimeographed.

Lee, Valerie E. and Marlaine E. Lockheed. 1990. "The effects of single-sex schooling on achievement and attitudes in Nigeria," Comparative Education Review 34, no.2: 209-231.

Lloyd, Cynthia B. and Ann K. Blanc. 1996. "Children's schooling in subSaharan Africa: The role of fathers, mothers, and others." Population and Development Review 22, no. 2: 265-298.

Lockheed, Marlaine E. and Adriaan M. Verspoor et al. 1991. Improving 
Primary Education in Developing Countries. Oxford: Oxford University Press.

Longman, Jere. 1996 . "When Loroupe runs, the women of Kenya run along with her," New York Times. 13 October: Section B, pp. 11-12.

Makau, Benjamin M. 1994. "Review of significant statistics on education of girls and women in Kenya," National Symposium on Education of Girls, Machakos, Kenya.

Masolo, D. A. 1988. You and Your Society: A Social Education and Ethics Course for Forms 3 and 4. Nairobi: Longman Kenya Ltd.

Masolo, D. A. and J. J. Ongonga. 1987. You and Your Society: Social Education and Ethics For Junior Secondary Schools. Nairobi: Longman Kenya Ltd.

Meekers, Dominique, Anastasia Gage, and Li Zhan. 1995. "Preparing adolescents for adulthood: Family life education and pregnancy-related school expulsion in Kenya," Population Research and Policy Review 14: 91-110.

Mensch, Barbara, Margaret Greene, and Judith Bruce. 1997. "Adolescents in the developing world: A review of population research and programs," unpublished manuscript.

Miller, Robert et al. 1997. The Situation Analysis Approach to Assessing Family Planning and Reproductive Health Services: A Handbook. New York: Population Council.

Montgomery, Mark R. and Cynthia B. Lloyd. 1996. "High fertility, unwanted fertility and children's schooling." paper presented at the National Academy of Sciences Workshop on Education and Fertility in the Developing World, 29 February - 1 March, Washington, DC.

Nunn, Andrew J. et al. 1994. "Risk factors for HIV-1 infection in adults in a rural Ugandan community: A population study," AIDS 8, no. 1: 81-86.

Obura, Anna P. 1991. Changing Images: Portrayal of Girls and Women in Kenyan Textbooks. Nairobi: ACTS Press. 
Sadker, Myra and David Sadker. 1995. Failing at Fairness: How Our Schools Cheat Girls. New York: Simon \& Schuster.

Sadker, Myra, Joyce Bauchner, David Sadker, and Leslie Hergert. n.d. "Observer's manual for intersect: Interactions for sex equity in classroom teaching," unpublished manuscript.

Stromquist, N. 1989. "Determinants of educational participation and achievement of women in the third world: A review of the evidence and a theoretical critique," Review of Educational Research 59, no 2: 143-183.

Stromquist, N. 1994. "Gender and education," in Torsten Husen and T. Neville Postlethwaite (eds.), The International Encyclopedia of Education, second edition, vol. 4, pp. 2407-2412. Tarrytown, NY: Elsevier Science/Pergamon.

United Nations. 1995. Women's Education and Fertility Behavior: Recent Evidence from the Demographic and Health Surveys. New York: United Nations.

Yates, Barbara A. 1982. "Church, state, and education in Belgian Africa: Implications for contemporary third world women," in Gail P. Kelly and Carolyn M. Elliott (eds.), Women's Education in the Third World: Comparative Perspectives, pp. 127-151. Albany: State University of New York Press.

Youri, Pat (ed.). 1993. Female Adolescent Health and Sexuality In Kenyan Secondary Schools: A Research Report. Nairobi: African Medical and Research Foundation. 


\title{
P OLICY RESEARCH DIVISION WORKING PAPERS
}

\author{
Recent Back Issues
}

*83 Sajeda Amin, Ian Diamond, and Fiona Steele, "Contraception and religious practice in Bangladesh."

84 John B. Casterline, Aurora E. Perez, and Ann E. Biddlecom, "Factors underlying unmet need for family planning in the Philippines."

85 Geoffrey McNicoll, "Governance of fertility transition: Regularity and du-ress." *86 John Bongaarts, "Population pressure and the food supply system in the de-veloping world."

87 Sajeda Amin, "Family structure and change in rural Bangladesh."

*88 John Bongaarts and Susan Cotts Wat-kins, "Social interactions and contem-porary fertility transitions."
*89 Cynthia B. Lloyd and Mark R. Montgomery,

"The consequences of unin-tended fertility for investments in chil-dren: Conceptual and methodological issues."

* 90 Zeba Sathar and Sonalde Desai, "Work patterns in rural Pakistan: Intersections between gender, family, and class."

*91 Mark R. Montgomery, "Learning and lags in mortality perceptions."

92 Ann E. Biddlecom, John B. Casterline, and Aurora E. Perez, "Men's and wom-en's views of contraception."

\section{6}

94 John Bongaarts and Sajeda Amin, "Pros-pects

for fertility decline and implica-tions

for population growth in South

Asia." 